INTERNATIONAL JOURNAL OF

MULTIDISCIPLINARY STUDIES IN ARCHITECTURE

AND CULTURAL HERITAGE

\title{
New Approach for Digital Technologies Application in Heritage Architecture Conservation
}

\section{Ola Mohammed Mahmoud Mohammed Ahmed a, *}

\begin{abstract}
Heritage is the memory of people for culture, arts, history, literature, customs, traditions and human innovations linked to the non-concept of our memory and it represents human creativity in architecture and our contribution to the enrichment of civilization, which is linked to the tangible history of our culture. Cultural and historical attractions are important factors for the development of tourism, which stimulates the growth of heritage industry. Societies and people have many cultural heritage, historical architecture and heritage interior spaces, heritage which are considered great importance and ancient history. Therefore, the preservation of culture and heritage to the future is the responsibility of everyone from the degradation processes, which arise from environmental factors, erosion, destruction and others. As cultural heritage is a vital element of modern society and the most important component of identity in modern times. Nowadays, the study of digital technology is an important field in the study of historical architecture conservation. In addition, the role of architects and designers in these processes is magnificent importance. Thus, the continuous evolution of digital technology creates new approaches to conservation science and documentation, leading to new methodologies, which can restore the degradation of architecture and can maintain interior functions of the building. The main concern is the usage of technological solutions to preserve the architecture and interior spaces, as well as, studying the connection between restoration and documentation and their roles in conservation of architecture heritage. Focusing on various techniques to study, analyze and protect historical buildings is essential. As digital
\end{abstract}




\begin{tabular}{ll}
\hline Keywords & \\
- & Material Science \\
- & Nanotechnology. \\
- & Nanomaterials. \\
- & Art Conservation. \\
$-\quad$ & Digital \& Physical Preservation. \\
- & Virtual Reality. \\
$-\quad$ & Historical Attractions. \\
- & Heritage Attractions. \\
- & Nanoparticle. \\
\hline
\end{tabular}

\section{Introduction}

Natural disasters such as earthquakes have caused great damage to heritage buildings (figure 1). The heritage is preserved in an unconscious manner and traditional methods of restoration, which lose the historical value of heritage buildings, works of art, Sculptures and many other fields of art which preserve heritage. Our society and our human behavior are changing because of the massive progress in technology an d how we will live in the future, so that, new technologies have a great role in preserving the heritage in different arts fields ("International training program in 
built heritage conservation," 2010). Cultural heritage is an expression of the life ways developed by society and passed on from generation to generation, including customs, practices, places, objects, artistic expressions and values ("What is Cultural Heritage," 2014). Many countries have a cultural dimension , a great architectural in its heritage buildings. Heritage buildings are structures of a distinctive architectural style from a single or collective structure which reflect the characteristics of a certain time period or an automatic structure and reflecting a local, rare , unique environment, national history, events, historical figures or a tourist attraction characterized by its artistic value. In addition, the contents of thosebuildings of accurate technical details are very important to conserve them, contribute and increase attention to them.

\subsection{Heritage of traditional buildings in changing surroundings (Why heritage is important?)}

Heritage is collective property which tells the history of a people, city or territory, and is passed on from generation to generation. Heritage makes it possible for generations to understand theirplace in history to better deal with the steady mutations of society: it is the element of stability in a rapidly changing world. All civilizations have left many legacies to today's world. The study of this heritage 
creates a new vision for today and better prepare for the future. The conservation of heritage is complex and it must be dealt with through multiple disciplines. However, for various reasons, the value of this heritage has not always been recognized. For along time, the heritage has been neglected, abandoned by its owners so their lost whole parts of the local heritage which often threatened by the influence of natural forces (rain, wind, vegetation ...) (Figure 1) (Figure 2) (Figure 3).
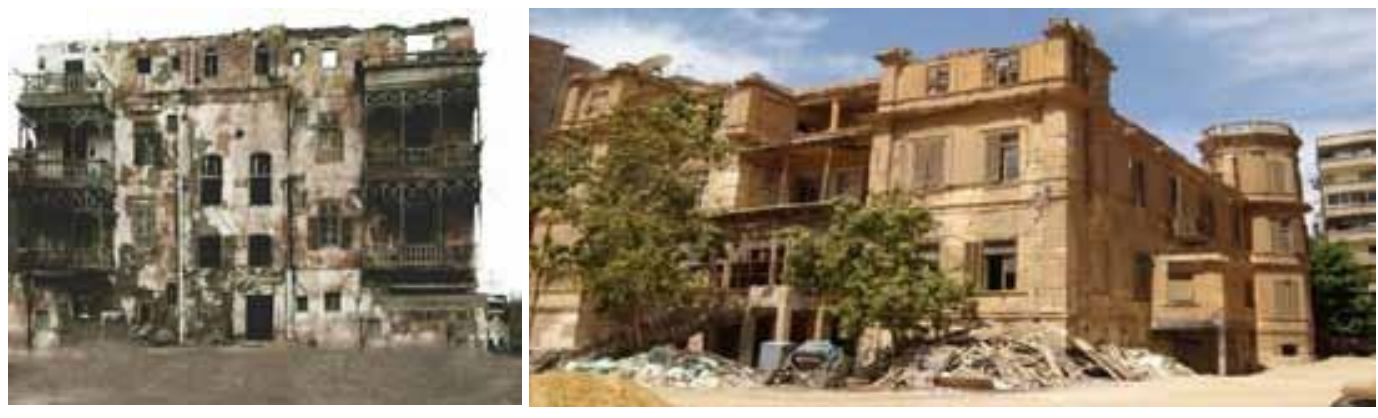
Figure 1. Demolition and neglect of architecture heritage in El Max, Alexandria and Villa Ambron, house to the great British author Lawrence Durrell ("Villa Ambron," 2018).

\subsection{Material and intangible heritage}

Material and intangible heritage are however closely related. The research deals the conservation and the opportunities offered by digital technologies: Conservation is a general concept which includes strategies to protect and promote heritage, materials science, digital applications, virtual reality, digital photogrammetry where research focuses on architectural heritage (Brusaporci, 2017). Heritage can be divided into two main categories which include a material, tangible form such as archaeology, art, architecture. In addition, another form is "Intangible Cultural heritage". So that, the research shifts from a study in the concepts of "conservation" to the constantly evolving idea of "heritage". Then it refers to the importance of heritage building as a reference for the study of tangible and intangible heritage.

\subsection{The era of modern digital transformation in Digital heritage}

The continuity of digital heritage is essential, in addition, the preservation and restoration of cultural heritage is a difficult field (Balliana, Ricci, Pesce, \& Zendri, 
2016). Digital heritage consists of unique resources of human knowledge and expression. Many of these resources have lasting value, importance and thus constitute a heritage which must be protected, preserved for present and future generations. The purpose of the digital heritage preserving is to remain accessible to public (UNESCO, 2003). In addition, preservation of stone heritage is a delicate and complex challenge. It is necessary to choose the appropriate materials and procedures for proper conservation treatment (Sierra-Fernandez, Gomez-Villalba, Rabanal, \& Fort, 2017). Hence, heritage conservation is an advanced practice, linking many disciplines between the technical, engineering and cultural sectors. it is a complex process, requiring multiple information to be applied at multiple levels, besides, using multimedia (Srinivas,

2018). This exchange has become an essential role in the interpretation, maintenance of natural, cultural heritage sites and sustainable management, as well as understanding issues and exploring the methods adopted in this field. The research highlights the most innovative trends in digital conservation techniques and architectural backgrounds (Brusaporci, 2017).

\subsection{Innovative reuse of cultural heritage - challenges and opportunities in the digital world}

Preserving heritage can be conducive to stimulate tourism and attract customers. Communities have a large stock of heritage buildings ("What is heritage conservation? A brief overview," 
2018). The research depends on challenges which confront architecture heritage, the use of latest technologies and biomaterials for protection, conservation, preservation, digital expansion, visualization, digital applications in preserving architectural heritage and interior spaces. The research demonstrates the enhancement and consolidation of advanced tools withindigital heritage research and application of technology in innovative reuse of architecture.

\section{Challenges and Problem}

The research deals the impact of the relationship of digital technology in the preservation of architectural heritage and heritage buildings. In addition, there are many challenges which face heritage in merge technology in architecture heritage to explore innovative approach in architecture and interior spaces and conserve to green heritage. Consequently, the research discusses a range of digital and biological technologies and their role in preserving the architectural heritage. These techniques constitute new methodologies in the process of conservation, restoration and revival of heritage. The process of preservation of heritage interferes with many rules and accurate methodologies. The competent authorities must be united to preserve the heritage, requiring the overlap of all specialists. 


\section{Important standards in heritage preservation which include:}

1. Does not lose its value and importance.

2. Cannot hurt the long-term impact.

The problem of research is the lack of full awareness by architects and designers of the way heritage is revitalized through restoration, reconstruction, repair, or adaptive reuse. Digital technologies and bio-materials solve many problems in heritage buildings which need restoration, maintenance or re-adaptation and green heritage. In addition, it is important to follow many methods which do not lose the importance of the impact and do not harm in the long run without a clear vision followed by the team in charge of preserving the impact.

\section{Objectives}

- This paper is to present and analyze some of technological methods to preserve architectureheritage. In addition, it preserves the value of buildings and thus increases their value by protection their original form and architectural elements, preferring instead to replace them.The research aims to revive the architectural heritage without damaging it in the long run to clarify the importance of using technology to preserve the heritage without losing its value using sustainable natural technologies and materials which lead to the green heritageto conserve natural resources.

- Study the relation between material science, architecture heritage and the 
effective impact of Nanotechnologies in conservation of heritage architecture.

- Analyze the applications of advanced technology in the field of preservation of heritage buildings to maintain of heritage buildings and protect them for tourism.

- Focus on the digital role where technologies can be useful tools for preserving heritage andit shows how digital technologies adapt into conservation issues to protect heritage.

\section{Research Methods}

Architectural heritage is defined through "continuous processes of modification and transformation across time (Brusaporci, 2017). Strengthening theoretical knowledge about architecture is essential in linking conservation practices among specialists in natural and cultural heritage. Therefore, it provides designers and architects with basic knowledge of heritage conservation and management, including concepts, perspectives and methodologies associated with the interpretation and analysis of architectural heritage. So that, any project for conservation is based on knowledge and understanding the historical and aesthetic value. The research is divided into three sections through successive processes and integrated to each other, including conservation, materials science and documentation. The research studies several interrelated fields to preserve heritage and access to a green heritage. 

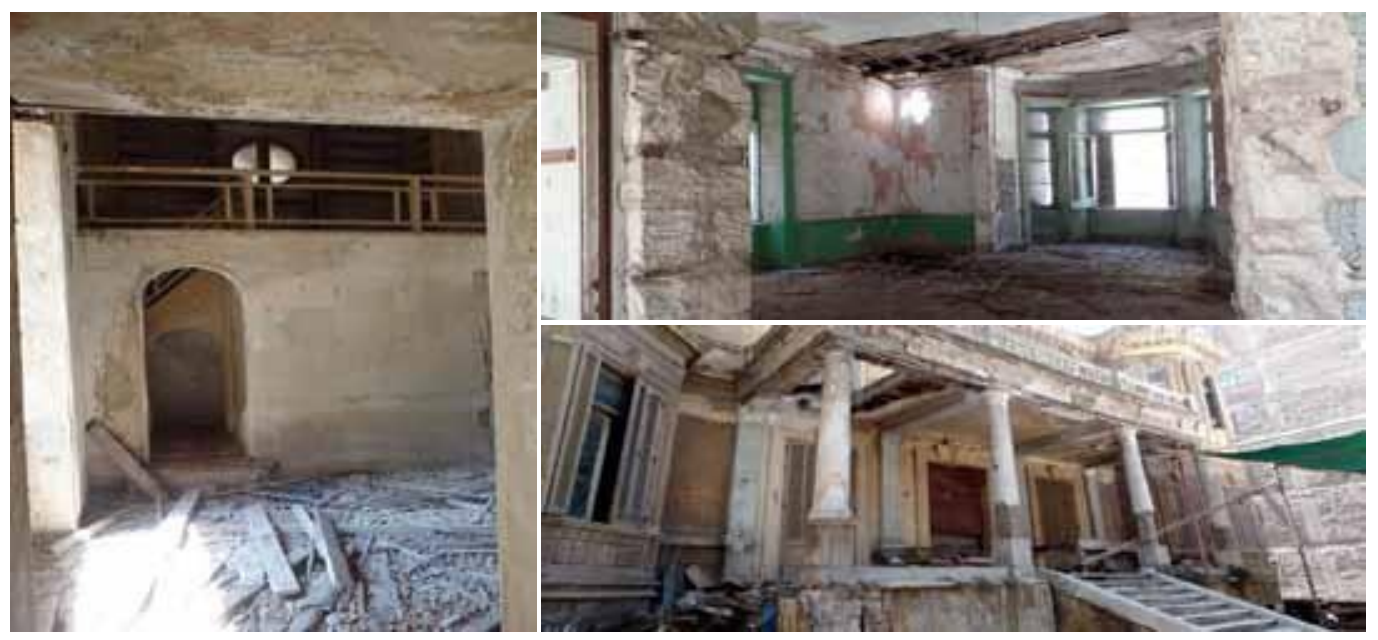

Figure 2. Lawrence Durrell's Tower in Alexandria and the extreme neglect of architectural heritage. 


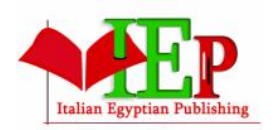

\section{INTERNATIONAL JOURNAL OF \\ MULTIDISCIPLINARY STUDIES IN ARCHITECTURE \\ AND CULTURAL HERITAGE}
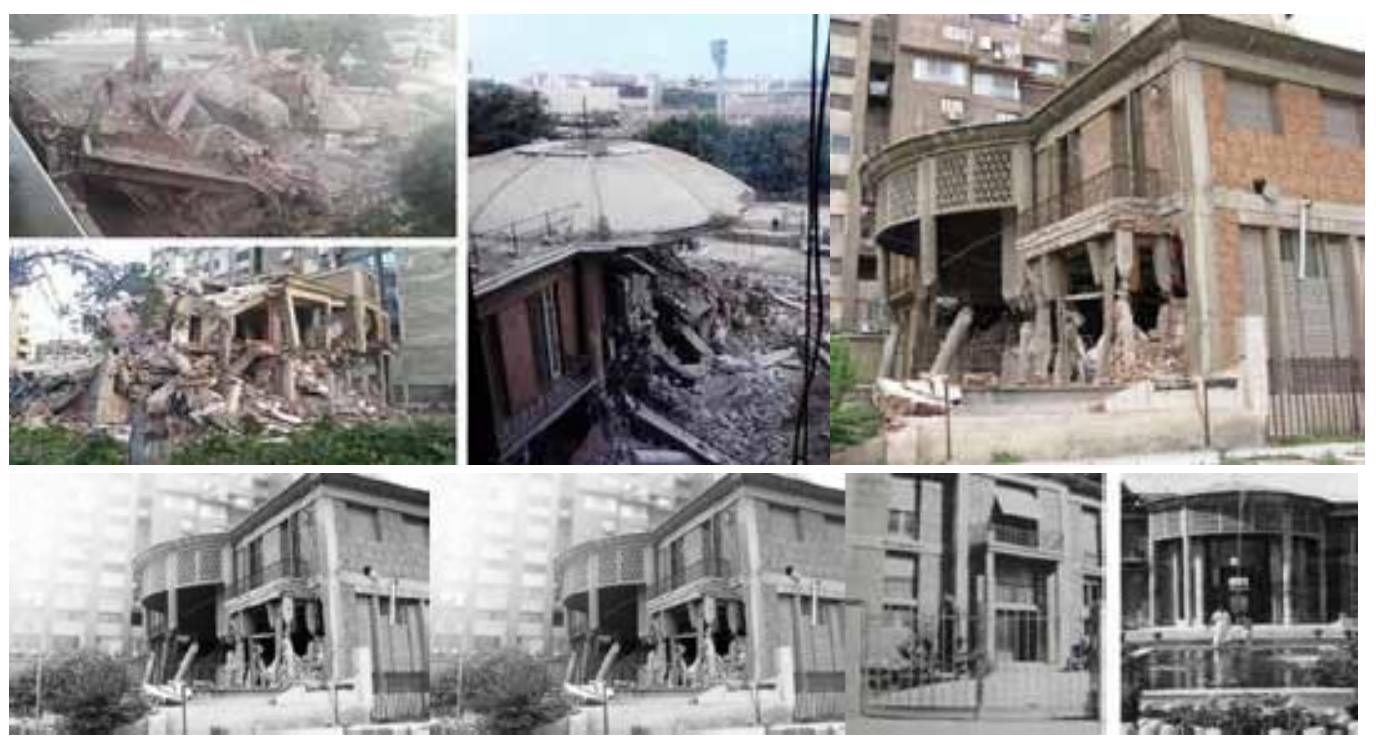

Figure 3. villa Aghion design after the collapse in Alexandria.

1. FIRST SECTION: Heritage Building Conservation and restoration

Conservation is the first stage in the preservation of heritage, which determines the appropriate method to protect the architectural heritage. Architectural conservation focuses on the protection of 
heritage from environmental damage to materials, form and structure, combining architectural design between science, arts, crafts and technology to achieve the desired result ("Heritage Building Conservation," 2018). Digital Conservation \& Restoration is based on conservation ethics and restoration principles.

\subsection{Digital techniques and methods for conversation heritage in architecture}

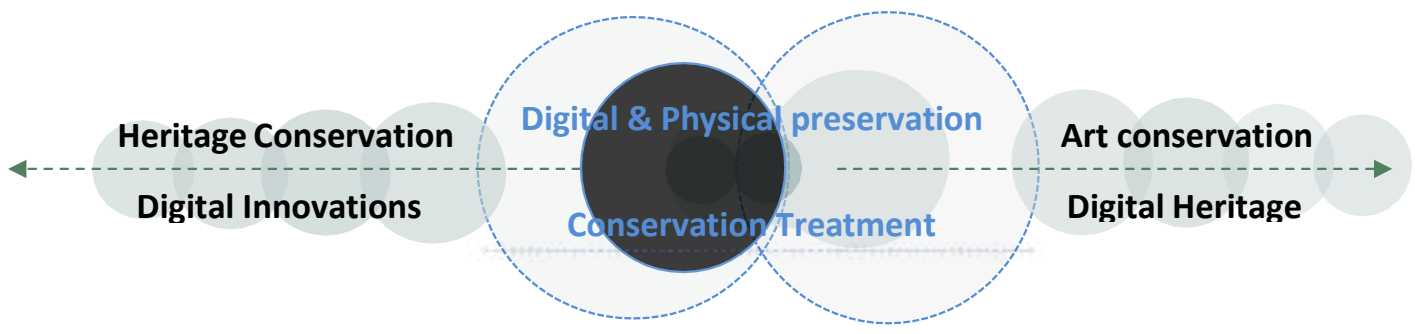

Figure 4. Diagram of elements for digital conversation heritage.

\subsection{Use of new digital techniques conserving architectural heritage}

Digital techniques are applied naturally to our lives, daily work and culture. Artists, designers, architects, musicians, theorists and cultural institutions increasingly rely on digital technologies, data production, storage and distribution of digital content in different ways. Digital technology seems to be fully integrated into scientific 
analysis processes whichpreserve historical architecture.

\subsection{Historical Heritage Criteria}

\section{Heritage Conservation could be divided into three parts:}

1. Natural Heritage.

2. Cultural Heritage (monuments, group of buildings, Sites).

3. Combination of natural and cultural heritage.

\subsection{New Methodologies for the Conservation of Cultural Heritage}

1.

\section{Conservation Treatment 2. Identification, Restoration}
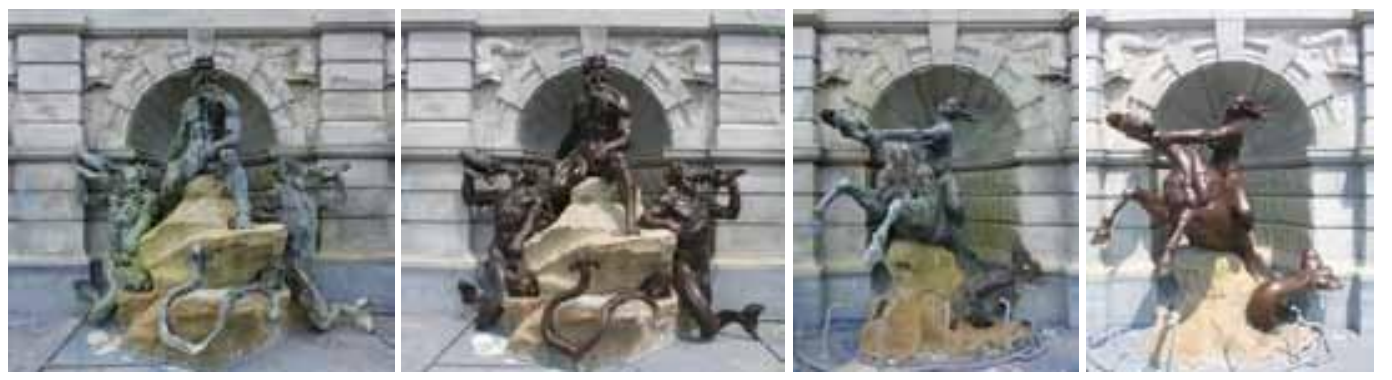

Figure 5. Identification, conservation, restoration of outdoor metallic sculpture of the Library of Congress (LOC) from the XIXth to the beginning of the XXth century ("The Library of Congress (LOC)," 2018). 


\section{CONSERVATION}

\section{A. STONES CONSERVATION}

\section{LIMESTONE SCULPTURE CONSERVATION - RIVERSIDE CHURCH project in}

New York, NY, 2008. Sculpture Conservation, Deterioration of Sculpture. The architecture was built of limestone and ornamented with a group of sculptures with contemporary art decostyle of its time. The project explained before and after the restoration where a plan has been developed to treat the damage, prevent further decay, and restore the missing elements. Molds were taken from weak attributes to be used in replication. The cracks and losses were drilled back to the sound stone while preserving the original carved surfaces, then the losses were rebuilt again to restore the lost features. After processing, the statues were combined ("LIMESTONE SCULPTURE CONSERVATION - RIVERSIDE CHURCH project," 2008). 

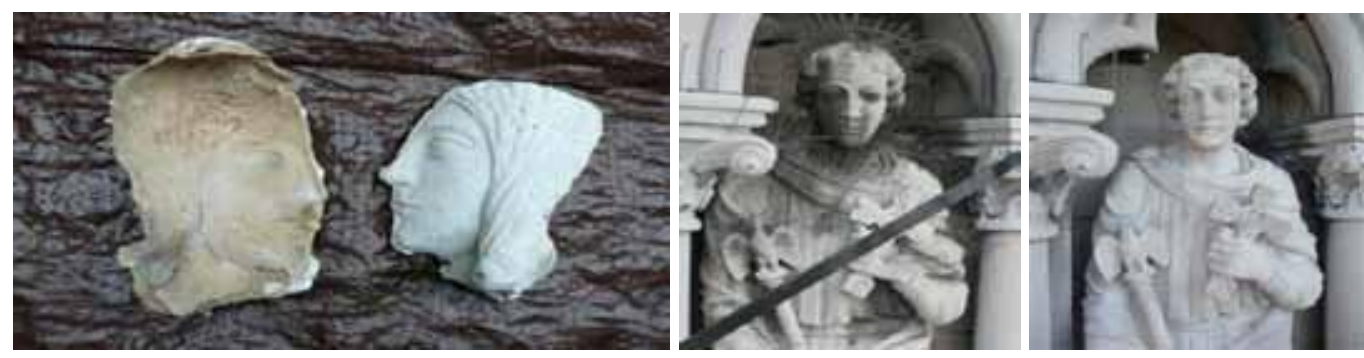

Figure 6. Modeling Replacement for Sculpture Losses, Sculpture Conservation, Face Replica. The project showed a hard shell formed on the outside of many sculptures, while thebasic stone materials have been eroded leaving only loose grains. The cracks formed on the surfaces to expose the damaged interior to the water and caused the full elements to fall (Figure 7). Materials / Limestone, Mortar.

Services Provided / Research-Documentation, Conservation Treatment. 

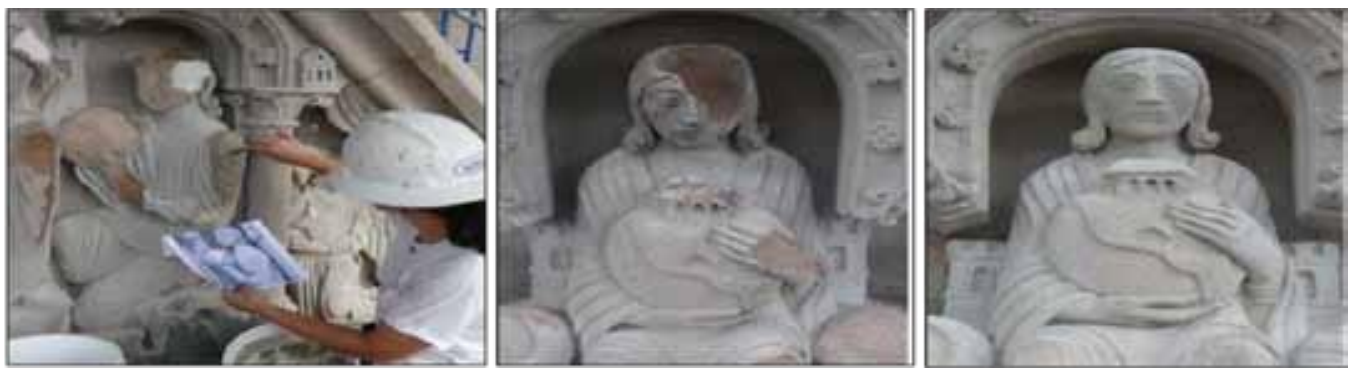

Figure 7. Riverside Church Sculpture Before Treatment, Riverside Church Sculpture After Treatment.
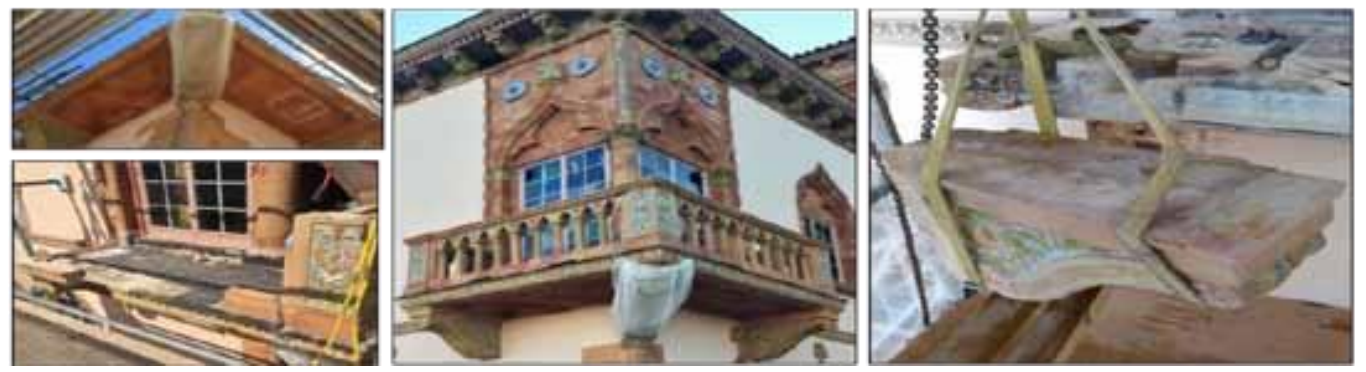

Figure 8. ORNAMENTAL TERRA COTTA RESTORATION - RINGLING MUSEUM OF ART project in John \& Mable Ringling Museum of Art in 
Sarasota, FL, 2015-2017. Research depended on exposure to salt spray with strong infrared rays of the sun, erosion of structural metal structures and cracking. It provided recommendations for stabilizing andtreating the balcony where it was carefully dismantled, in addition, the exposed steel substrateswere cleaned of corrosion. The crushing units have been removed for repair, besides, it will bereplicated according to a new design which allowed for thermal expansion during extremetemperature fluctuations. The facade of the building was restored and painted to suit the colorof the adjacent paint, then the terrace was reassembled ("ORNAMENTAL TERRA COTTA RESTORATION - RINGLING MUSEUM OF ART project," 2017). Materials / Terra Cotta.

Services Provided / Conservation Treatment, Surveys-Condition Assessment.

Services Provided / Research-Documentation, SurveysCondition Assessment, ContractDrawings-Specifications.

\section{A. METALS CONSERVATION}

$\begin{array}{ccccc}\text { 1.Surveys-Condition } & \text { 2.Research- } & \text { 3.Testing- } & \text { 4.Conservation } \\ \text { Assessment } & \text { Documentation } & \text { Analvsis } & \text { Treatment } \\ & & & \end{array}$


Figure 9. Diagram of metal conservation stages.
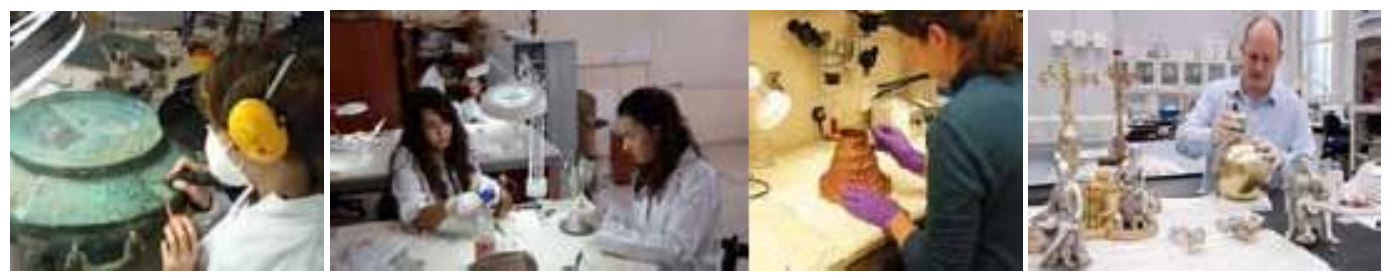

Figure 10. The team tested various techniques to safely remove unwanted corrosion products, samples from a variety of coatings to match the original finish, and performed tests to repair the missing original paint areas.

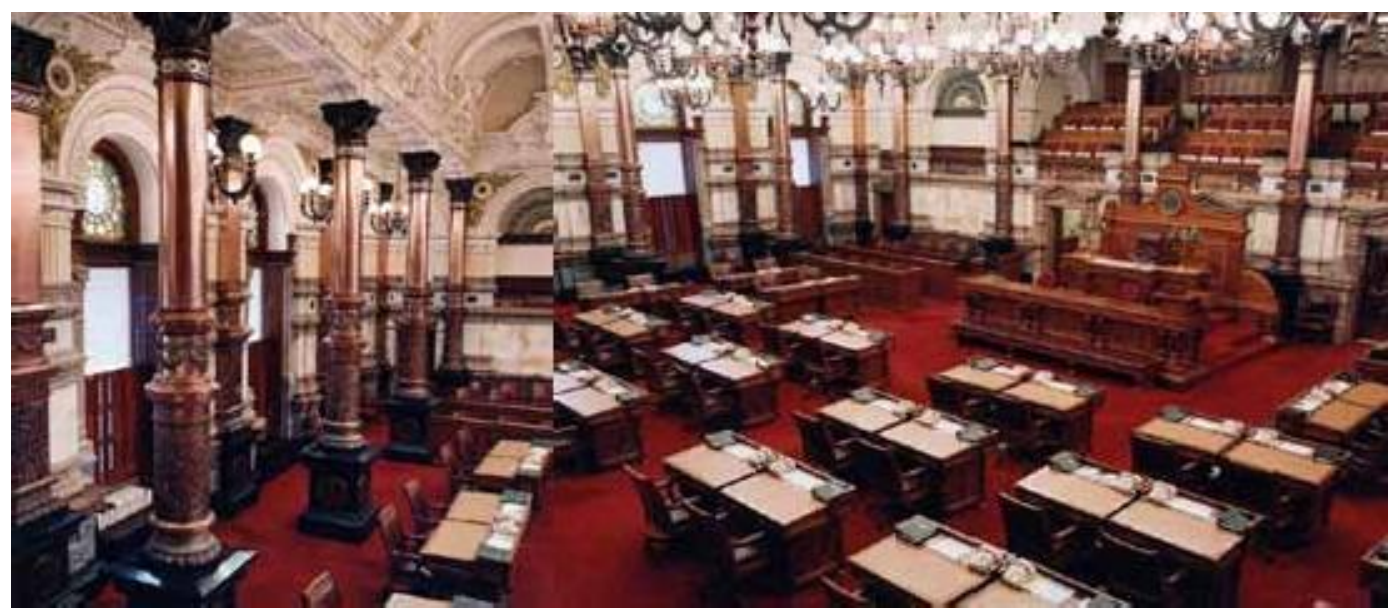


Figure 11. SENATE CHAMBER METALS CONSERVATION KANSAS STATE

CAPITOL project in Topeka, KS, 1999.
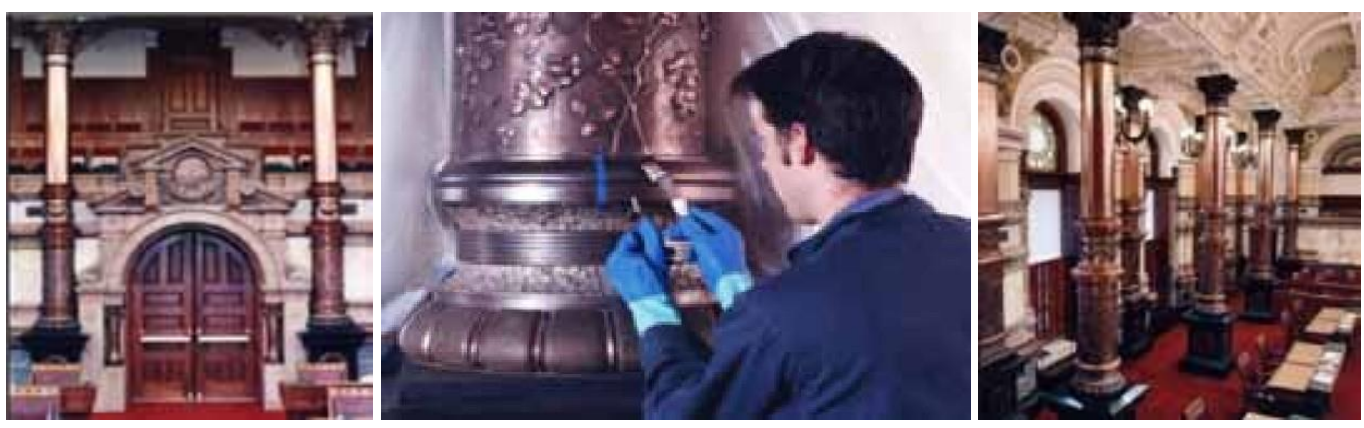

Figure 12. Bronze Columns at the Kansas State Capitol Senate Chamber, Metal Architectural Elements at the Kansas State Capitol Senate Chamber, Bronze Conservation Treatment. The Senate Chamber was a unique artistic work ornamented in 1885 . The round windows, which feature faceted stained glass, were imported from France. The walls were decorated with various exotic materials from all over the world. 
The research team reviewed historical documents, besides, conducted on-site tests to determine the originalappearance of metals and their degradation and cause nature (Figure 11). The 28 columns were ornamented with ornate panel, decorative ornaments and wall grids so that all surfaces could be accessed. Old protective coatings and corrosion products have been removed from copper, silver and the missing parts have been removed and re-installed. Large areas of loss of paint and new castings were replaced on site using brushing technique (Figure 12) ("SENATE CHAMBER METALS CONSERVATION KANSAS STATE CAPITOL project," 1999).

Materials / Electroplated Cast Iron, Stamped Copper, Cast Bronze, Nickel/Silver.

Services Provided / Surveys-Condition Assessment, ResearchDocumentation, Testing- Analysis, Conservation Treatment. 



Figure 13. Development, restoration and reviving of Darwish Theater Project. Dome of Whirling Dervishes Ceremony hall at the Mevlevi Tekke, a meeting hall for the Sufi order and Whirling Dervishes, Cairo, Egypt. 


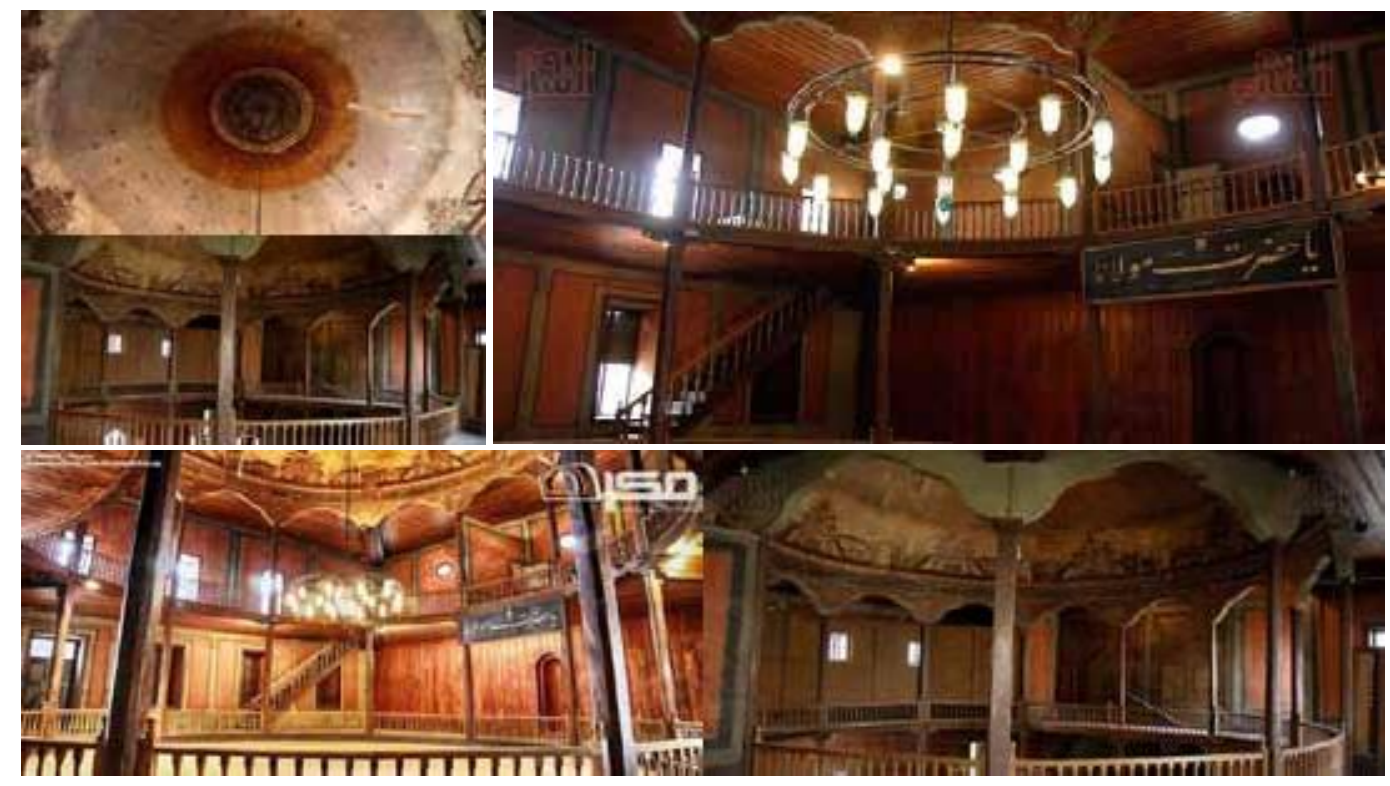

Figure 14. Darwish Theater consists of a round wooden platform surrounded by a circleand surrounded by a wooden railing. The second floor is a wooden staircase which leads to irregular spaces and it have been allocated for the audience and spectators. The Hall is based on 12 columns, eight windows and eight decorative units. The building combines the Ottomanand Mamluk styles and it is divided into three spaces (Figure 14). 




Figure 15. The center of the theater from the ceiling dome is one of the most important signs of Tikkiyah, it is built on twelve wooden columns, each containing a name of the twelve imams of the Muslim Shiites, followed by rectangular areas containing cumulativewritings in Arabic letters. The interior of the dome is decorated with natural landscapes, including Turkish statues, flags, 


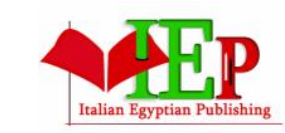

ISSN: $2735-4415$
INTERNATIONAL JOURNAL OF

MULTIDISCIPLINARY STUDIES IN ARCHITECTURE

AND CULTURAL HERITAGE

VOLUME 3, ISSUE 1, 2020, 1-68.

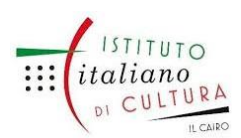

www.egyptfuture.org/ojs/

floral motifs and many illustrations of the Sufi philosophy onwhich the mulatto method is based (Figure 15).

\section{SECOND SECTION: Digital Trends and Cultural Heritage \\ [Material science and architecture heritage]}

There are many methodologies to preserve and protect the heritage through digital and biological technologies which reflect sustainable and more environmentally preserving heritage leading to green heritage. Instead of building on nature, biological materials and processes will be integrated into traditional engineering materials and processes (Figure 16).

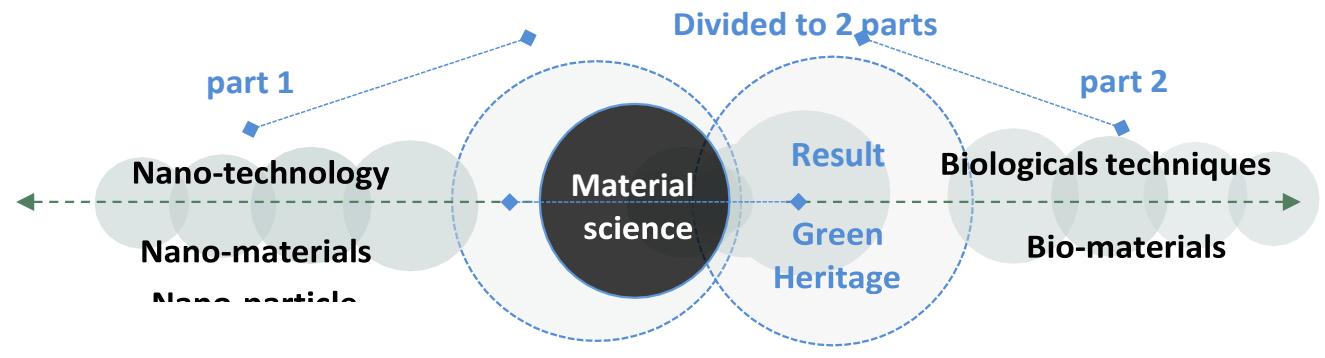

Science, Arts, Crafts technology and Digital, Biological

technologies Figure 16. The relationship between material science and conservation of heritage. 
INTERNATIONAL JOURNAL OF

MULTIDISCIPLINARY STUDIES IN ARCHITECTURE

AND CULTURAL HERITAGE

\begin{tabular}{|c|c|c|}
\hline $\begin{array}{l}\text { Technique/ } \\
\text { Description } \\
1 . \text { Cleaning }\end{array}$ & $\begin{array}{l}\text { Technique/ } \\
\text { Description }\end{array}$ & $\begin{array}{l}\text { nique/ } \\
\text { ription }\end{array}$ \\
\hline eaning & & -cleaning \\
\hline $\begin{array}{l}\text { - } \text { Cleaning is usually the } \\
\text { most expensive } \\
\text { process in the } \\
\text { restoration project. } \\
\text { - Solvents, } \\
\text { whether aromatic or } \\
\text { non- aromatic, and } \\
\text { other cleaning } \\
\text { products (ie, pickled } \\
\text { agents, light and } \\
\text { strong acids and } \\
\text { bases) are used } \\
\text { extensively in } \\
\text { maintenance and } \\
\text { applied to various } \\
\text { materials such as } \\
\text { plates, mural, etc. }\end{array}$ & $\begin{array}{l}\text { - Microemulsions are } \\
\text { used as cleaning } \\
\text { factors mainly on wall } \\
\text { paintings and stones, } \\
\text { because of their ability } \\
\text { for control and } \\
\text { transparency. } \\
\text { - Micro emulsifiers can } \\
\text { be considered green } \\
\text { because they require a } \\
\text { small amount of } \\
\text { solvents, thereby } \\
\text { reducing their toxicity } \\
\text { and environmental impact. } \\
\text { end }\end{array}$ & 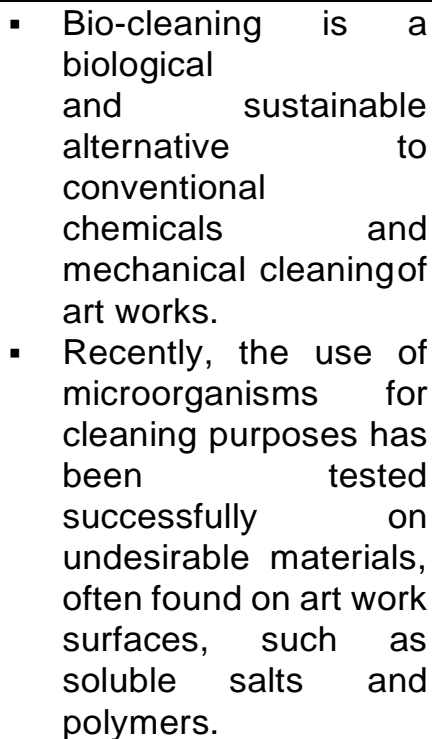 \\
\hline iquids & 5. Laser & 6. Gels \\
\hline
\end{tabular}


INTERNATIONAL JOURNAL OF

MULTIDISCIPLINARY STUDIES IN ARCHITECTURE

AND CULTURAL HERITAGE

\begin{tabular}{|c|c|c|}
\hline $\begin{array}{l}\text { - lonic fluids are used as } \\
\text { valuable substitutes } \\
\text { for dangerous } \\
\text { cleaning } \\
\text { methods in the } \\
\text { preservation of art } \\
\text { works. One of the } \\
\text { basic applications is a } \\
\text { green alternative to } \\
\text { cultural heritage. }\end{array}$ & $\begin{array}{l}\text { - The laser has been } \\
\text { used as an eclectic } \\
\text { and environmentally } \\
\text { friendly method of } \\
\text { cleaning, because it } \\
\text { cannot change or } \\
\text { affect the surface of } \\
\text { artifacts on a variety of } \\
\text { materials, such as } \\
\text { wood, metal, paper, } \\
\text { stone, easelplates and } \\
\text { wall paintings. }\end{array}$ & $\begin{array}{l}\text { - Gel use as a } \\
\text { supporting material or } \\
\text { as an effective } \\
\text { cleaning product in } \\
\text { cultural heritage } \\
\text { applications. High } \\
\text { viscosity allows the } \\
\text { release of solvents } \\
\text { gradually, which } \\
\text { reducessolubility. }\end{array}$ \\
\hline 7. Consolidation & 8. Nanotechnologies & 9. Bio-consolidation \\
\hline
\end{tabular}


INTERNATIONAL JOURNAL OF

MULTIDISCIPLINARY STUDIES IN ARCHITECTURE

AND CULTURAL HERITAGE

\begin{tabular}{|c|c|c|}
\hline $\begin{array}{l}\text { Consolidation is a very } \\
\text { difficult and sensitive } \\
\text { process in } \\
\text { conservation and } \\
\text { restoration, as it can } \\
\text { cause } \\
\text { undesirable } \\
\text { effects, such as yellowing, } \\
\text { and uneven } \\
\text { distribution of support. } \\
\text { Most synthetic } \\
\text { products (such as } \\
\text { acrylic polymers, vinyl, } \\
\text { silicon, } \\
\text { etc.). }\end{array}$ & $\begin{array}{l}\text { - Nanotechnology has } \\
\text { become increasingly } \\
\text { important in the care } \\
\text { of heritage, which can } \\
\text { facilitate the operation } \\
\text { of self-cleaning, } \\
\text { anti- microbial } \\
\text { treatment, or the } \\
\text { protection of materials } \\
\text { (Figure 17) (Kroftová, } \\
\text { Šmidtová, Kuřitka, \& } \\
\text { Škoda, 2017). }\end{array}$ & \begin{tabular}{lr} 
- & \multicolumn{2}{c}{ Bio-consolidation is a } \\
new methodology \\
based & on \\
selected & \\
microorganisms & capable \\
of settling & stone \\
materials & and \\
producing & inorganic \\
compounds & (Figure \\
18). &
\end{tabular} \\
\hline 10. Protection & 11. Bio-polymers & 12. TiO2 nanoparticles \\
\hline
\end{tabular}


INTERNATIONAL JOURNAL OF

MULTIDISCIPLINARY STUDIES IN ARCHITECTURE

AND CULTURAL HERITAGE

\begin{tabular}{|c|c|c|}
\hline $\begin{array}{l}\text { - Innovative } \\
\text { methodologies have } \\
\text { been applied } \\
\text { from the } \\
\text { application of } \\
\text { nanoscale } \\
\text { polymerization and } \\
\text { TiO2 coatings. }\end{array}$ & $\begin{array}{l}\text { The use of bio- } \\
\text { polymers may have } \\
\text { advantages in terms } \\
\text { of ecological } \\
\text { compatibility, } \\
\text { reversibility } \\
\text { and biodegradability. }\end{array}$ & $\begin{array}{l}\text { - } \mathrm{TiO} 2 \text { uses } \\
\text { nanoparticles as self- } \\
\text { cleaning and anti- } \\
\text { microbial. }\end{array}$ \\
\hline $\begin{array}{l}\text { 13. Infrared } \\
\text { Reflectography }\end{array}$ & $\begin{array}{l}\text { 14. Ultraviolet } \\
\text { Fluorescence } \\
\text { Photography }\end{array}$ & 15. living concrete \\
\hline
\end{tabular}


INTERNATIONAL JOURNAL OF

MULTIDISCIPLINARY STUDIES IN ARCHITECTURE

AND CULTURAL HERITAGE

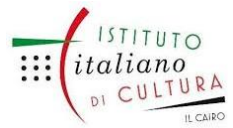

\begin{tabular}{|c|c|c|}
\hline $\begin{array}{l}\text { High } \\
\text { resolution } \\
\text { multispectral } \\
\text { scanning over a wider } \\
\text { range of the } \\
\text { electromagnetic } \\
\text { spectrum can } \\
\text { be } \\
\text { undertaken by art } \\
\text { analysis and research. } \\
\text { It provides information } \\
\text { the artist's painting } \\
\text { process, and may help } \\
\text { with problems of } \\
\text { attribution. }\end{array}$ & $\begin{array}{l}\text { - } \text { Photography taken } \\
\text { under ultraviolet } \\
\text { illumination is used to } \\
\text { record information } \\
\text { about the artist's use } \\
\text { of medium, pigments } \\
\text { and varnish, in } \\
\text { addition, recording } \\
\text { areas of retouching. }\end{array}$ & $\begin{array}{l}\text { The problem with } \\
\text { traditional concrete is } \\
\text { the formation of } \\
\text { cracks. This has } \\
\text { negative } \\
\text { consequences for the } \\
\text { durability of the } \\
\text { material. } \\
\text { It produces the } \\
\text { biology of limestone to } \\
\text { heal cracks and } \\
\text { appears on the } \\
\text { surface of concrete } \\
\text { (Figure 21) (Figure 22) } \\
\text { (Jonkers, 2014). }\end{array}$ \\
\hline
\end{tabular}

Table 1. Methodologies to preserve and protect the heritage through digital and biological technologies (Balliana et al., 2016).

\subsection{MATERIAL SCIENCE: NANO-TECHNOLOGY (PART 1)}

\subsubsection{Application Nanotechnologies in digital Conservation of Heritage} Architecture

The impact of Nanotechnologies in Conservation of Heritage Architecture

1. Safe-by-Design nanotechnology for safer cultural heritage restoration (Figure 17). 
2. Facilitate the cleaning of contaminated surfaces and self-cleaning.

3. Anti-microbial treatment.

4. The protection of materials from the negative effects of ultraviolet radiation and others.

5. Focus on the different types of nanoparticles currently used in the production ofconservation (Figure 18).

6. Treatments with improved material properties and new functions.

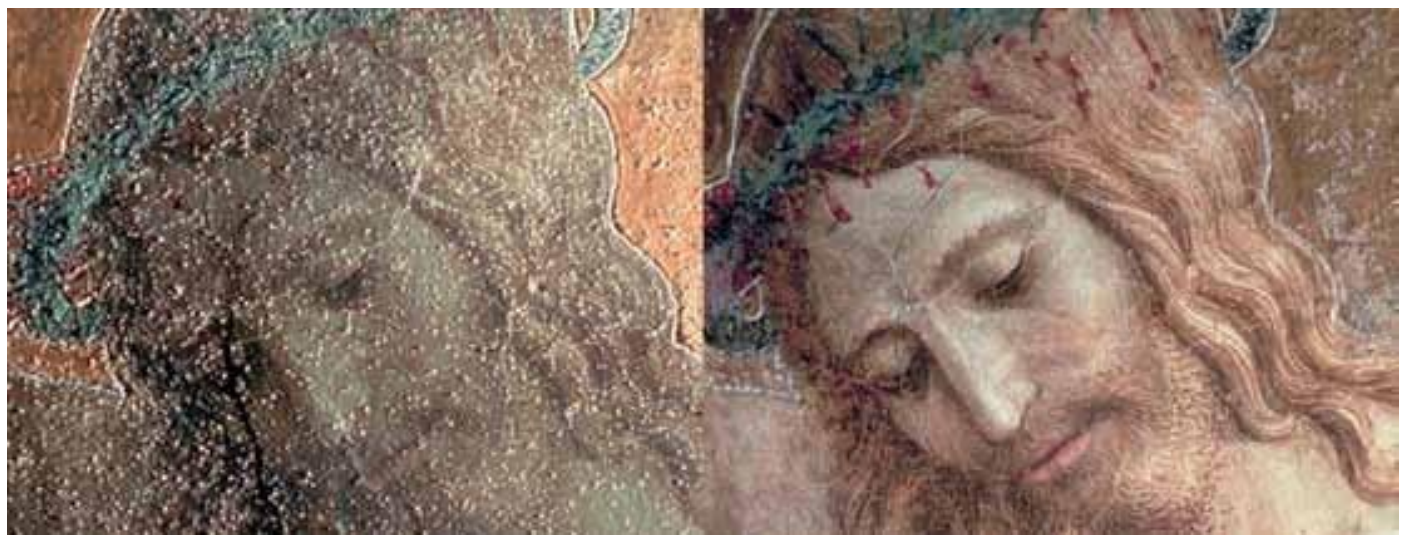

\section{Figure 17. Nanotechnologies and nanomaterials explore}


conservation, restoration of cultural heritage and preservation of art works.

\subsubsection{Nanotechnologies techniques for conservation heritage}

2. consolidation process.

\section{Nanoparticles.}

3. Nanoparticle can be effectively used to consolidate stone and paintings.
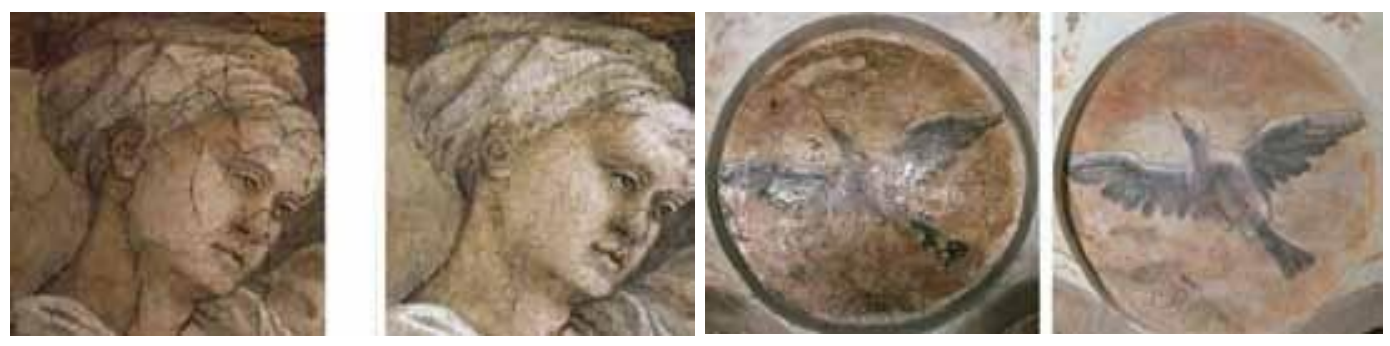

Figure 18. The restoration and conservation of a painting by nanotechnologies. Effect of consolidation process on works of art. before treatment; after consolidation (Figure 18).Nanoparticles are very small particles, with a dimension comprised between $1 \mathrm{~nm}$ and $100 \mathrm{~nm}$.

\subsubsection{Hydroxide Nanoparticles}




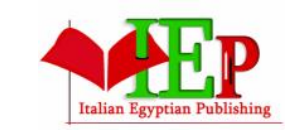

\section{INTERNATIONAL JOURNAL OF \\ MULTIDISCIPLINARY STUDIES IN ARCHITECTURE \\ AND CULTURAL HERITAGE}
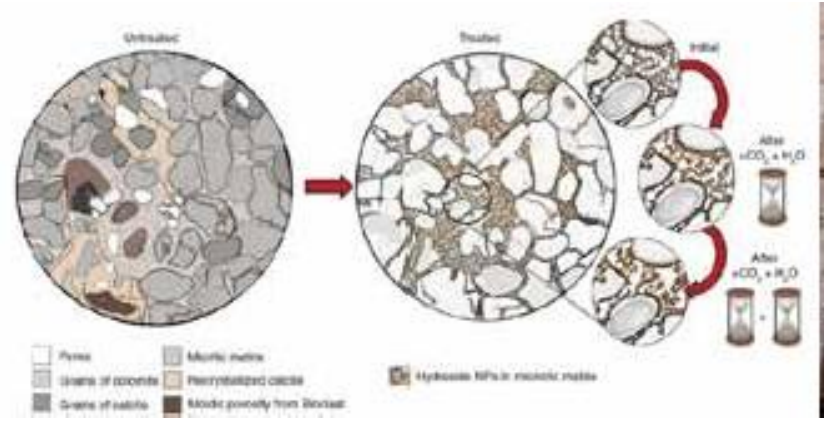

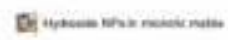
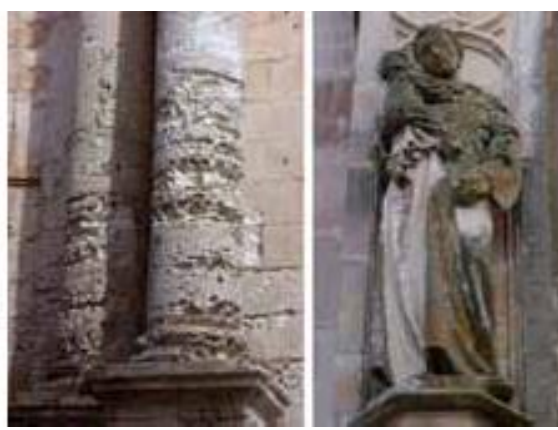

Figure 19. Thin film of dolostone before and after treatment with hydroxide nanoparticles.

Figure 20. Degraded stone heritage showing: salt weathering of building stone, visible microbial growth and staining (Sierra-Fernandez et al., 2017). 


\subsubsection{Bio-materials and heritage conservation}

Biotechnology plays a vital role in the preservation of architectural heritage and it is closely linked to the conservation process. In addition, it can preserve the heritage without harming itin the long
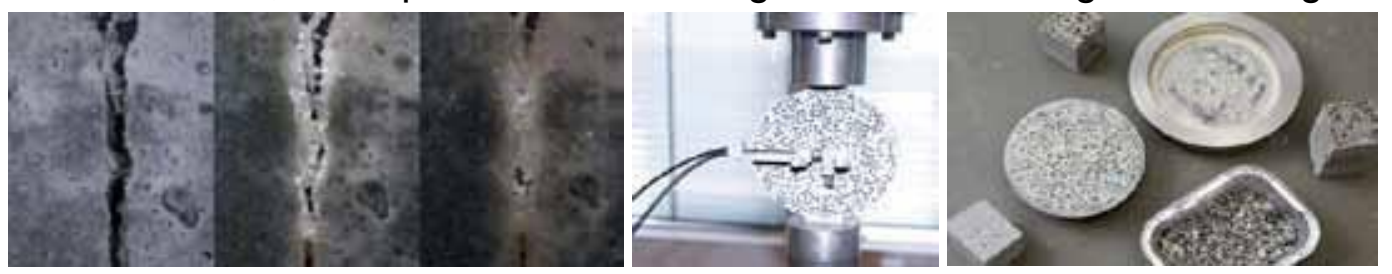

run and can treat the effects of natural factors to reach a green heritage (Figure 21).

Figure 21. Self-Healing concrete can repair its own cracks with bacteria ("Self-Healing Concrete," 2016). Figure 22. The living concrete which can heal itself with this selfhealing concrete, buildings repair themselves by closing the small cracks attributed to the entry of gases and liquids which can affect their durability (Tziviloglou, Pan, Jonkers, \& Schlangen, 2017) ("living concrete," 2016).

1. THIRD SECTION: Virtual technology, Documentation and Heritage conservation Digital technologies for surveying, modeling and 
This section studies Digital techniques for surveying, modeling and representation which have produced significant methodological changes in conservation heritage. In particular, documentation, laser scanning, photogrammetry, virtual reality, advanced software for modeling, data analysis, and computerbased visualization have transferred a historical process of knowledge towards the use of complex 3D models (Brusaporci, 2017).

\subsection{The virtual reality and its role in preserving heritage}

The research uses virtual reality to preserve heritage (loannides, M., Martins, J., Žarnić, R., Lim, 2017). Digital transformation may play a substantial role in protecting this heritage. It isimportant to

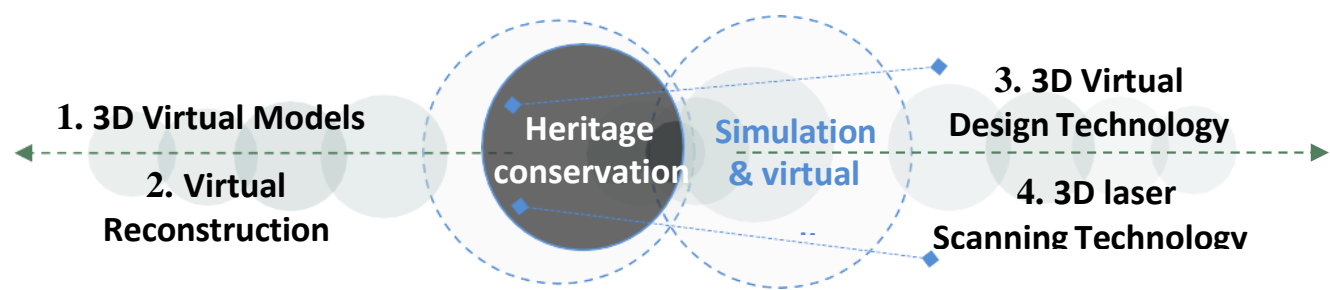

study digital technology in finding new solutions to preserve and document architectural spaces (Figure 23) ("Digital innovation can enhance cultural heritage," 2018). 


\section{Figure 23. Diagram of virtual technology techniques and heritage conservation.}

\subsection{Digital Documentation of cultural Heritage}

Documentation, digital Photogrammetry, laser scanning and other modern technologiesfacilitate creation, control and dissemination of accurate 3D models which can help conservatives in cultural heritage. They can offer higher and deeper accuracy to address new situations which may not be technically or financially accessible (Figure 23).

\subsection{Digital innovation can enhance cultural heritage}

- Digital technology is not just a new tool to visualize, explore or consume cultural heritage, otherwise, it can also help in conservation efforts. Digital documentation of heritage can take many different forms and use a wide range of technology ("Archaeology," 2018).

- Virtual Heritage is "the utilization of technology for interpretation, conservation and preservation of Natural, Cultural and World Heritage" (Brusaporci, 2017).

- Virtual Reality bases on a total-body immersion in a computer-generated environment.

- Photogrammetry is "the art, science, and technology of obtaining reliable information about physical objects and the environment through processes of recording and measuring". 


\subsection{The use of virtual 3D presentations in the conservation of architecture heritage}

Robotics, computer science and virtual reality have been applied to the study of cultural and heritage sites. As well as accurate documentation of cultural heritage is necessary to protect it, in addition, scientific studies carried out during the process of restoration and renovation (Figure 25). Proximity imaging has been used successfully to document cultural heritage. With recent advances in computer and information technology, this traditional method of near-term digital imaging has been replaced. Laser scanning is another technique which in recent years has become increasingly common for documents and provides highly dense 3D dots. Hence, 3D form and digital image can be created directly (NaciYastikli, 2007).

\subsection{Visualization \& Simulation}

Once the heritage site of the architecture and interior spaces is examined, it is translated and produced realistic images. New 3D modeling designs can be visualized or simulated in a virtual reality environment ("Visualization \& Simulation," 2018). 


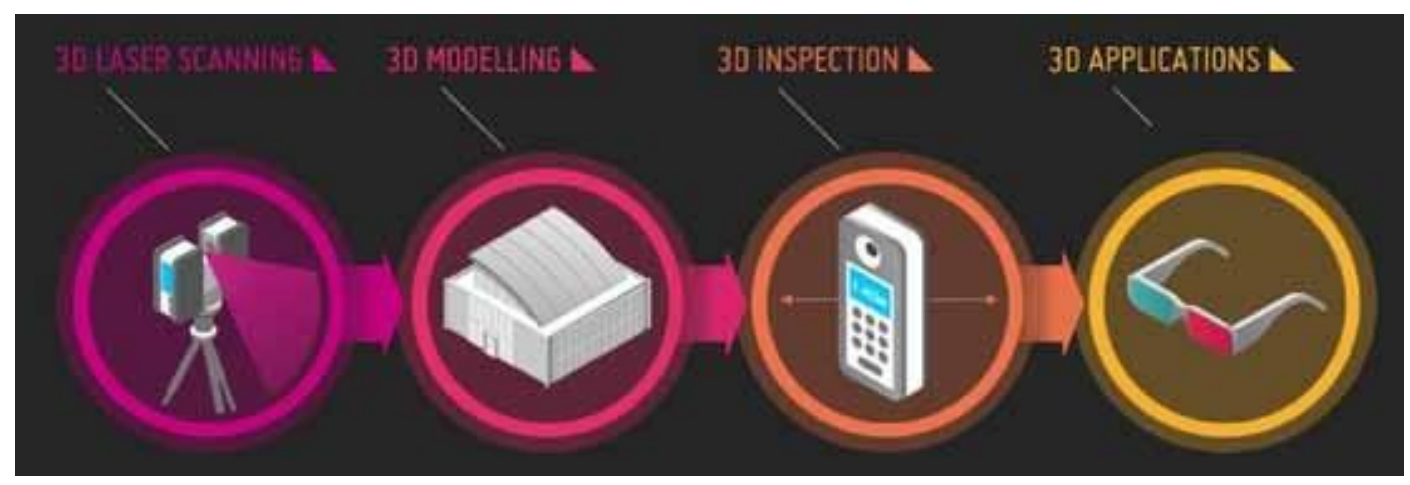

3D LASER SCANNING / 3D MODELLING /3D INSPECTION / 3D APPLICATIONS

Figure 25. Digital survey of cultural Heritage ("Digital survey of cultural Heritage," 2018).

\subsection{D Laser Scanning}

8 3D Laser Scanning is a complex scan for locations in a 3D image with minimal downtime. It gives the possibility to design potential improvements in the digital scene (Figure 24).

9 It is easy to scan huge sites with complex architectural features. However, conversion of this data into modeling of micro-structure 
information remains a challenge (Figure 25) (Figure 26)(Figure 27) (Figure 28).

9.1 Some of projects for application Virtual technology, Documentation and othertechniques in heritage conservation

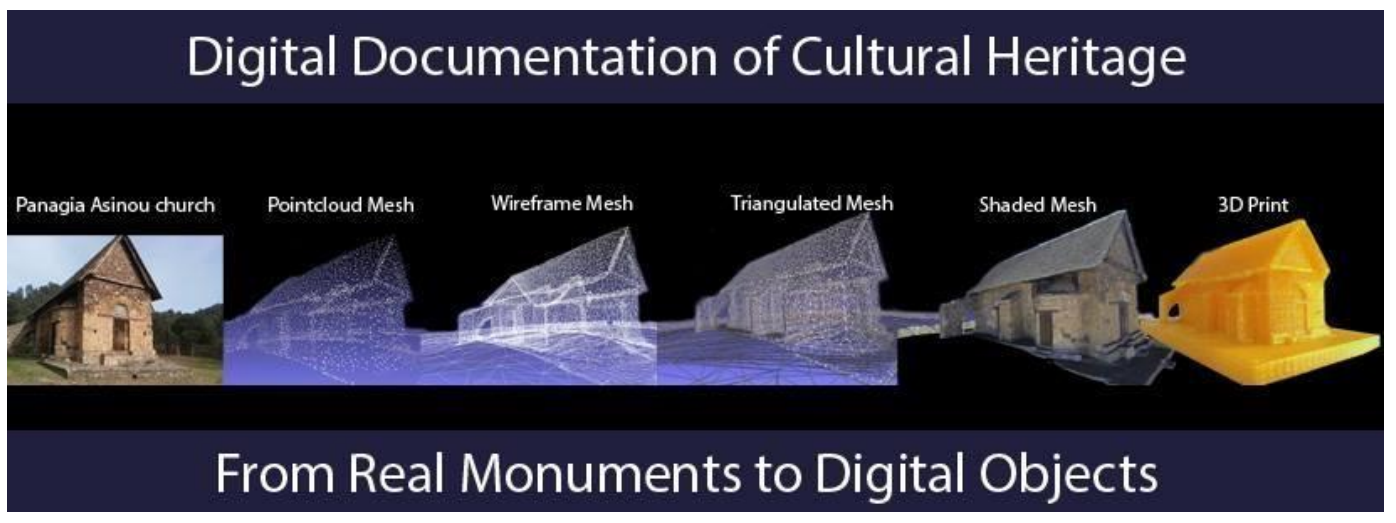

Figure 24. Digital Documentation of cultural Heritage from real building to digital objects ("Initial Training Network for Digital Cultural Heritage," 2018). 

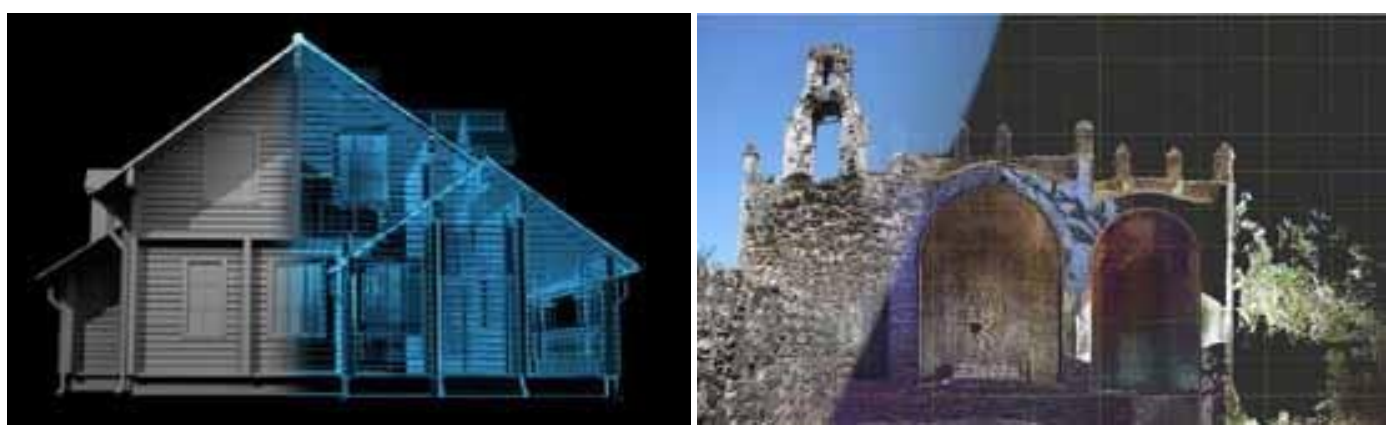

Figure 25. 3D Laser Scanning Architecture. Figure 26. A visualization of data collected at Ecab ("Digital Heritage Conference in Granada, Spain.," 2015).


39 
Figure 27. The 3D laser scanning survey of the Arco of Rua Augusta.

Figure 28. The Sydney Opera House project took more than 800 laser scans of the interior and exterior, and 56,000 digital photos, documenting 13 billion measurable points on the structure using cutting-edge, laser-mapping technologies ("3D laser scanning," 2013).

\subsubsection{The power of 3D scanning}

The study of digital documentation techniques provides accurate data for architectural heritage and interior spaces. Hence, the Specialists can determine the safe means used either through conservation, restoration or use of materials science, which includes nanotechnology technology and biological materials (Figure 29) (Figure 30) (Figure 40) (Figure 42). 

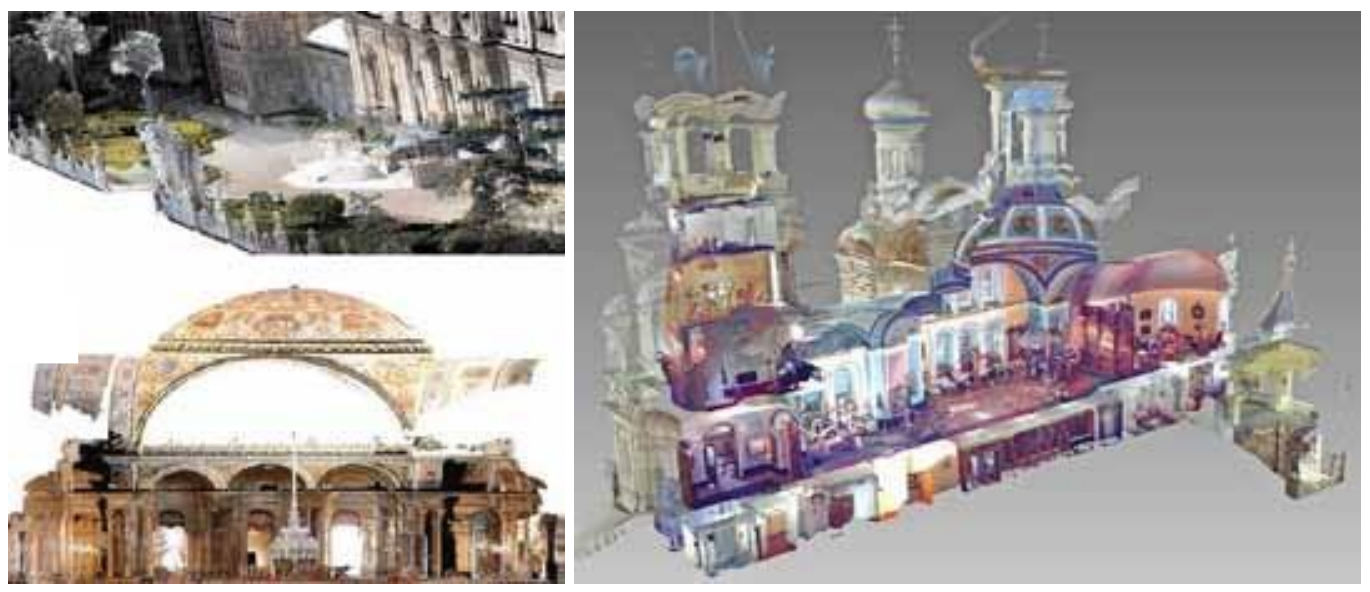

Figure 29. 3D Laser Scanning Architecture and a visualization of data collected at Ecab. 


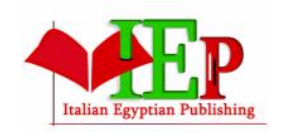

ISSN: $2735-4415$

\section{INTERNATIONAL JOURNAL OF \\ MULTIDISCIPLINARY STUDIES IN ARCHITECTURE \\ AND CULTURAL HERITAGE}

VOLUME 3, ISSUE 1, 2020, $1-68$.

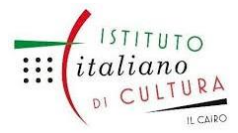

www.egyptfuture.org/ojs/
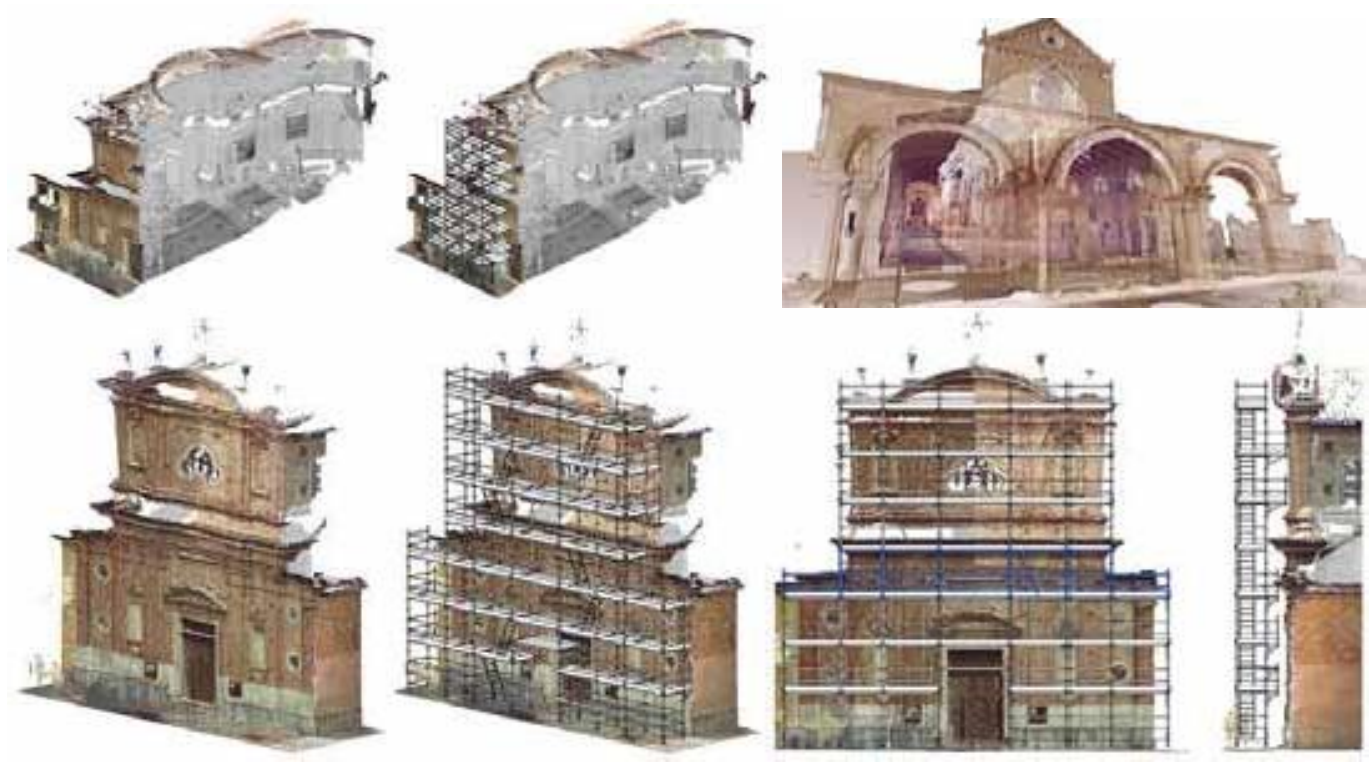

Figure 30. Digital photogrammetry and laser scanning ("Digital photogrammetry and laser scanning," 2018) (“3d scanning," 2018). 

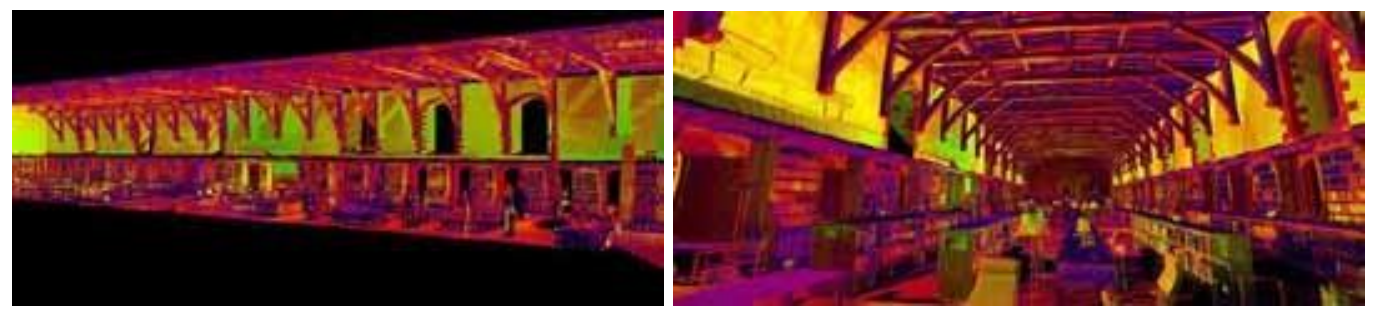

Figure 32. Digital Surveys 3D laser scanned the Cathedral cloisters and Monks Dormitories ("The Cathedral cloisters," 2018). The digital surveys completed a metric laser survey of the UNESCO World Heritage site at Cathedral cloisters, which it is the greatest example of Norman architecture in England. The survey required high-density point data to becaptured from several key areas within the cathedral (Figure 33). It began in 1093 and ended largely in 40 years. It was the only cathedral in England which retained almost all its craftsmanship, in addition, it maintained the integrity of its original design.

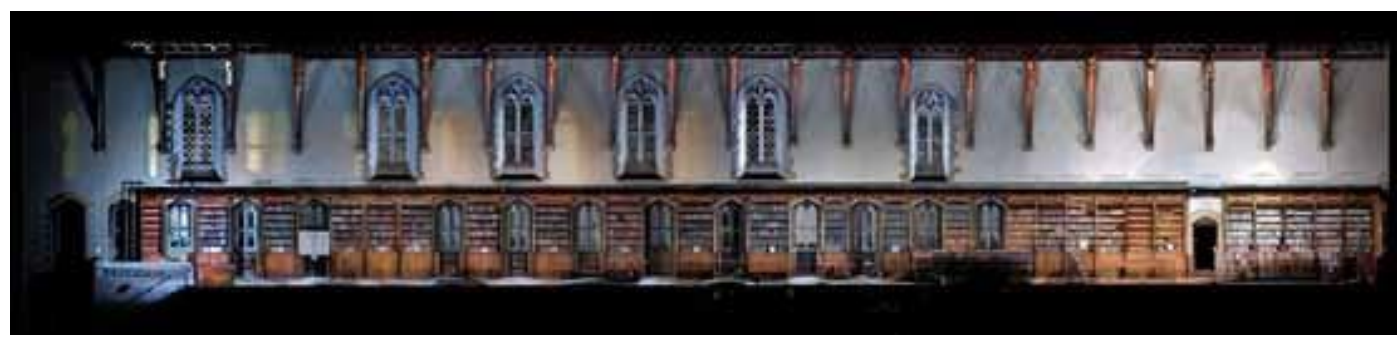

43 
Figure 33. As part of the conservation plans as well as providing a quick snapshot at the time, the laser scanning was used to create the detailed geometry and horizontal projections of the cathedral then determined the process of processing the church. A three-dimensional laser scan was performed over 10 days in the cathedral using a FaroPhoton120 laser scanner (Figure 34).

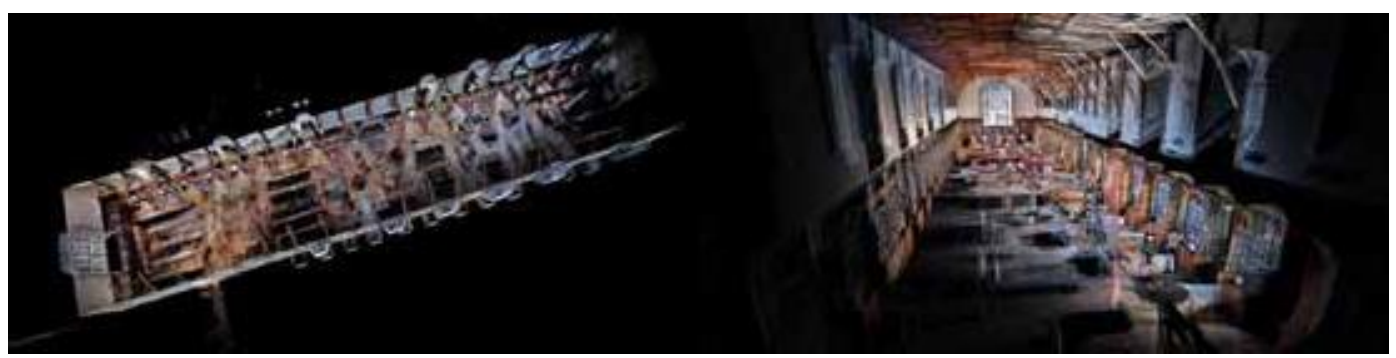

Figure 34. All scans were performed at a very high density and color photographs were also taken in each scan setting. All individual rooms were divided into groups and sub- clusters 


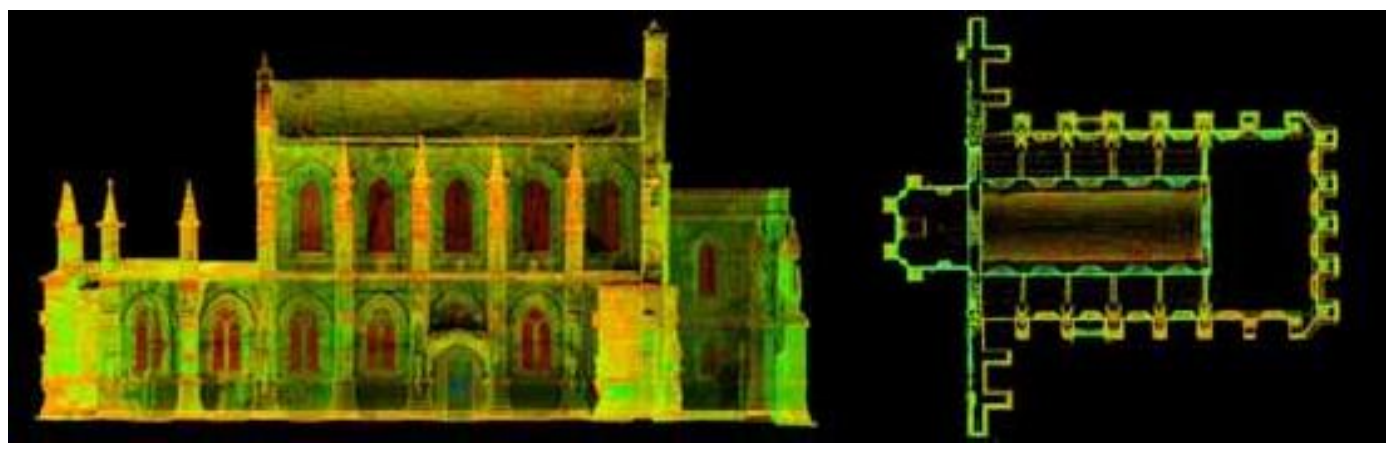

Figure 35. Center for Digital Documentation and Visualization, Glasgow ("Digital Documentation," 2018). Rosslyn Chapel was a medieval building which has been described as a "treasure of stone", a protected historic building. It was still used as a place of worship, as well as it was an international tourist destination, attracting more than 150,000 visitors annually(Figure 36).
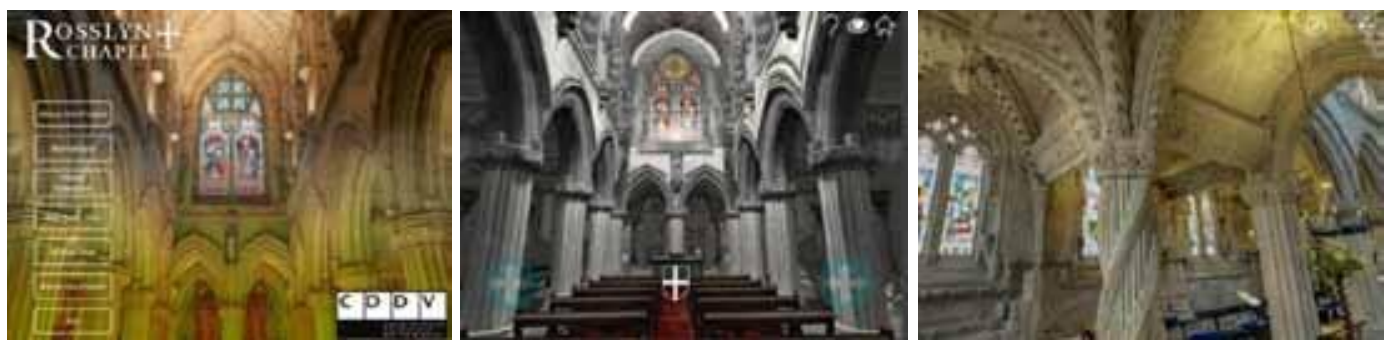
Figure 36. Rosslyn Chapel, 8 billion points scanned over 3 days by the Centre for Digital Documentation and Visualization, Glasgow. Since 2008, the Digital Documentation and Imaging Center had worked to document the interior and exterior of the Rosslyn Church and its land used advanced laser. Scanning and panoramic techniques were 360-degree. 3D laser scanning data had been developed to become a virtual 3D model of the chapel. Then it hadbeen explored the outer and inner part of the church used the 3D interactive model.

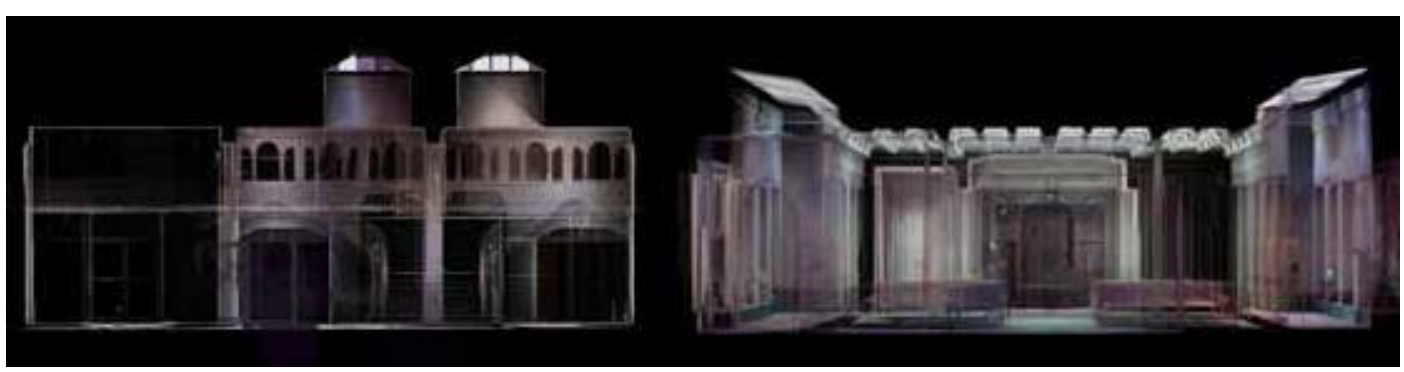

Figure 37. Elevations of Digital Documentation. 


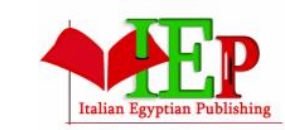

ISSN: $2735-4415$

\section{INTERNATIONAL JOURNAL OF \\ MULTIDISCIPLINARY STUDIES IN ARCHITECTURE \\ AND CULTURAL HERITAGE}

VOLUME 3, ISSUE 1, 2020, 1-68.

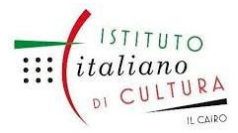

www.egyptfuture.org/ojs/

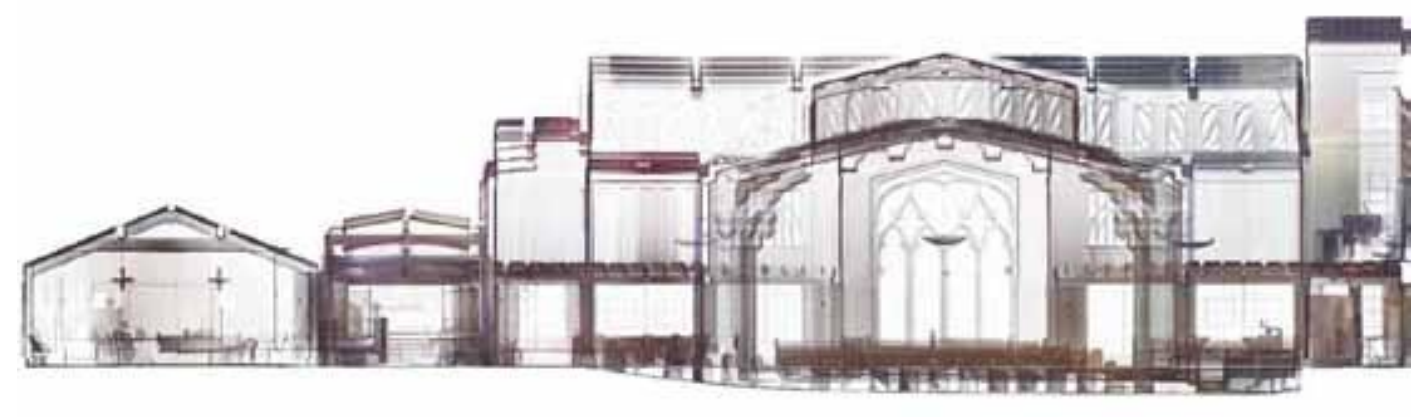

Figure 38. Section of church to document the interior heritage. 


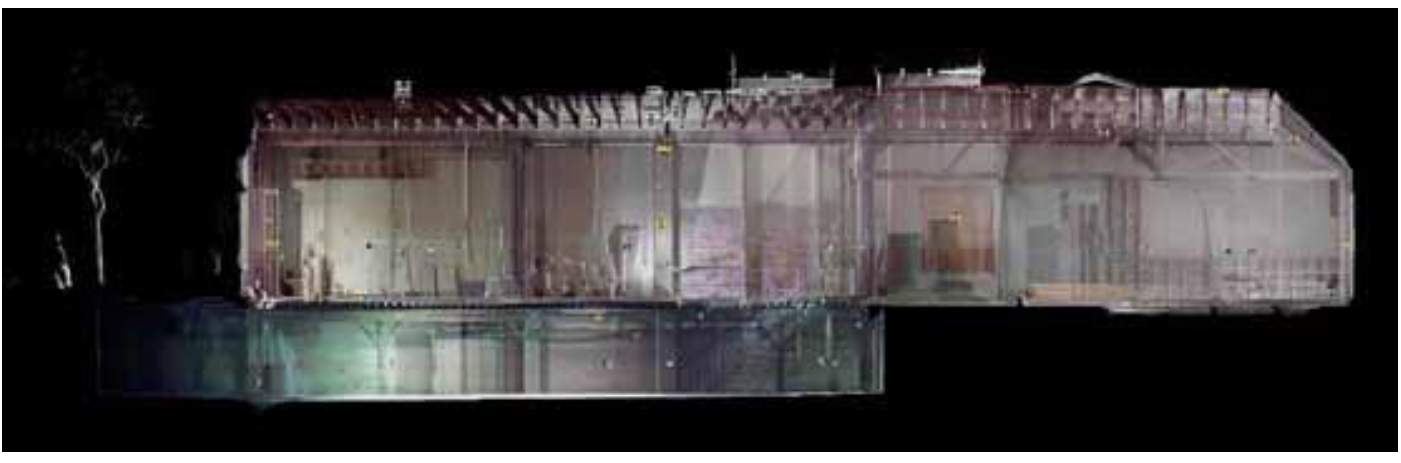

Figure 39. Section of historical building through 3D laser scanning technology.

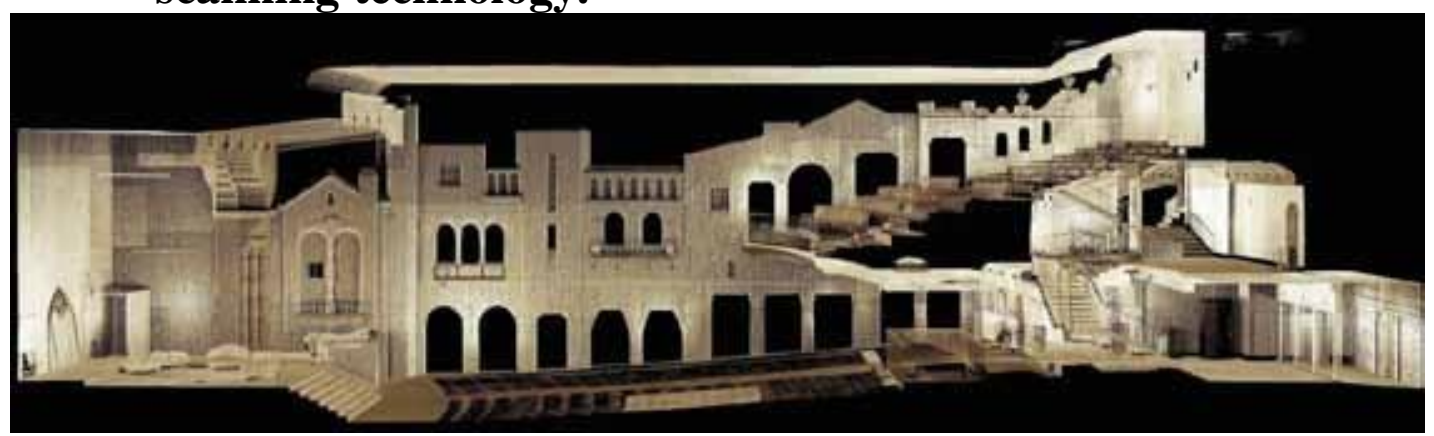

Figure 40. Virtual 3D model of documentation interior space. 


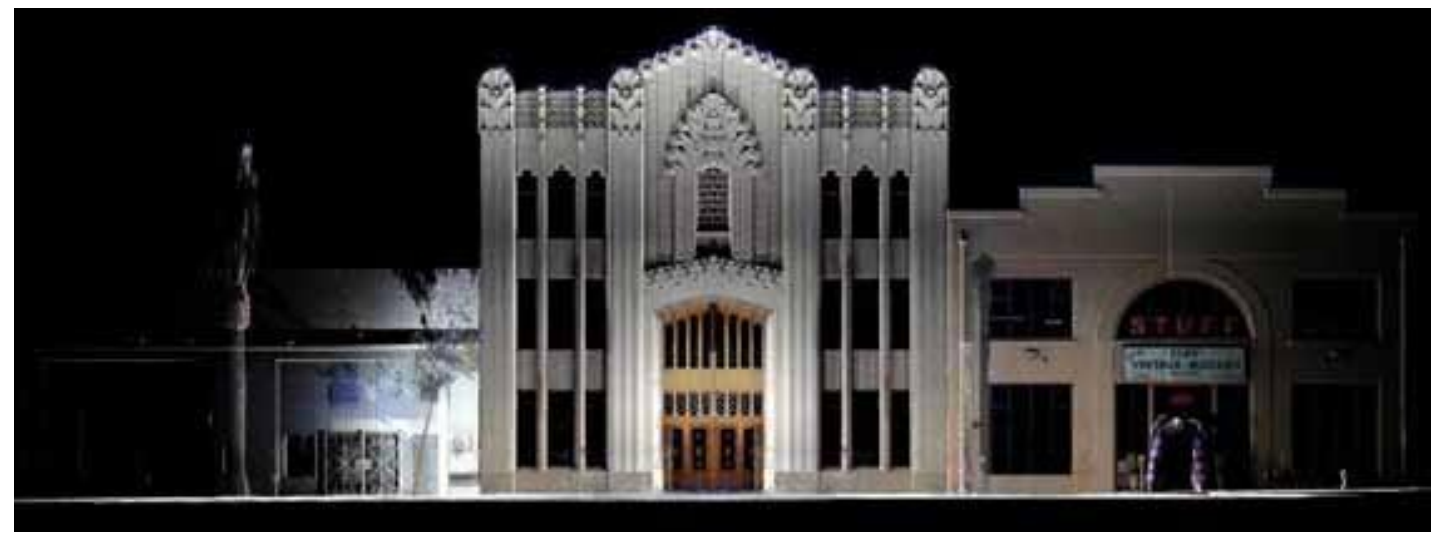

Figure 41. San Francisco Bay Area 3D Laser Scanning Projects (“3D Laser scanning,"2018).

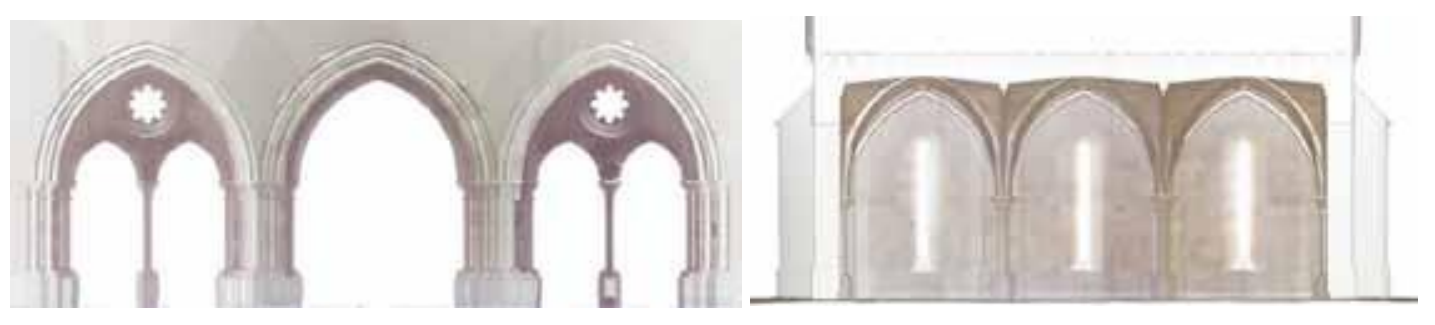




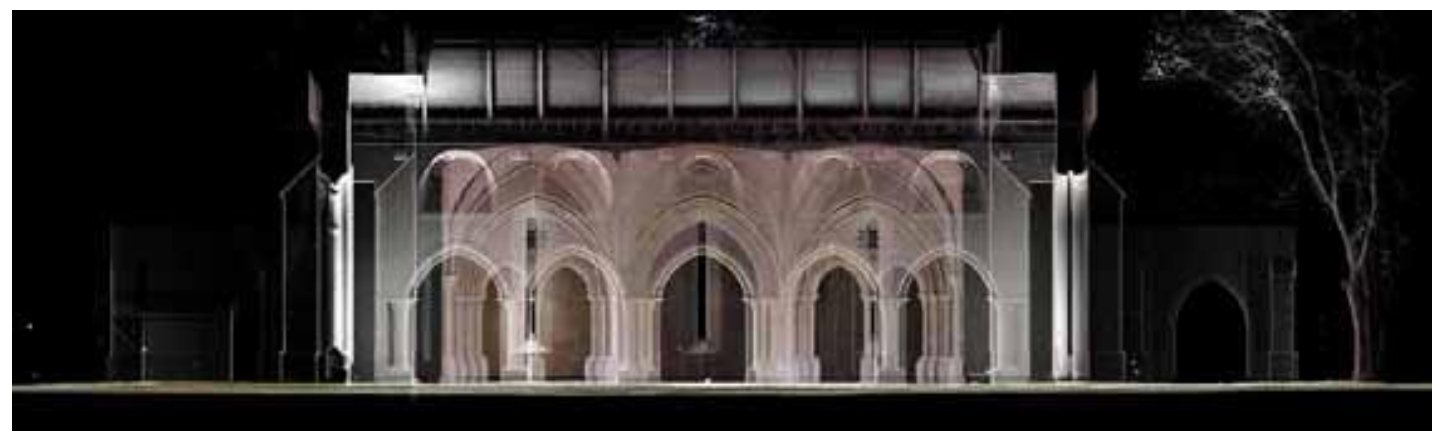

Figure 42. Sections of Churches, temples and shrines, may adapt to the needs of culture, or suffer from neglect and destruction, as in the past. old cinematic "palaces" may becomecenters of performance or severely cut in the inner shopping malls ("3D Laser scanning," 2018).

Figure 43. Sections of 3D laser scanning data. 
INTERNATIONAL JOURNAL OF

MULTIDISCIPLINARY STUDIES IN ARCHITECTURE

AND CULTURAL HERITAGE


Figure 44. Plan and perspective of Cistercian church project which included the reconstruction of the church and dates to the late $12^{\text {th }}$ century. 


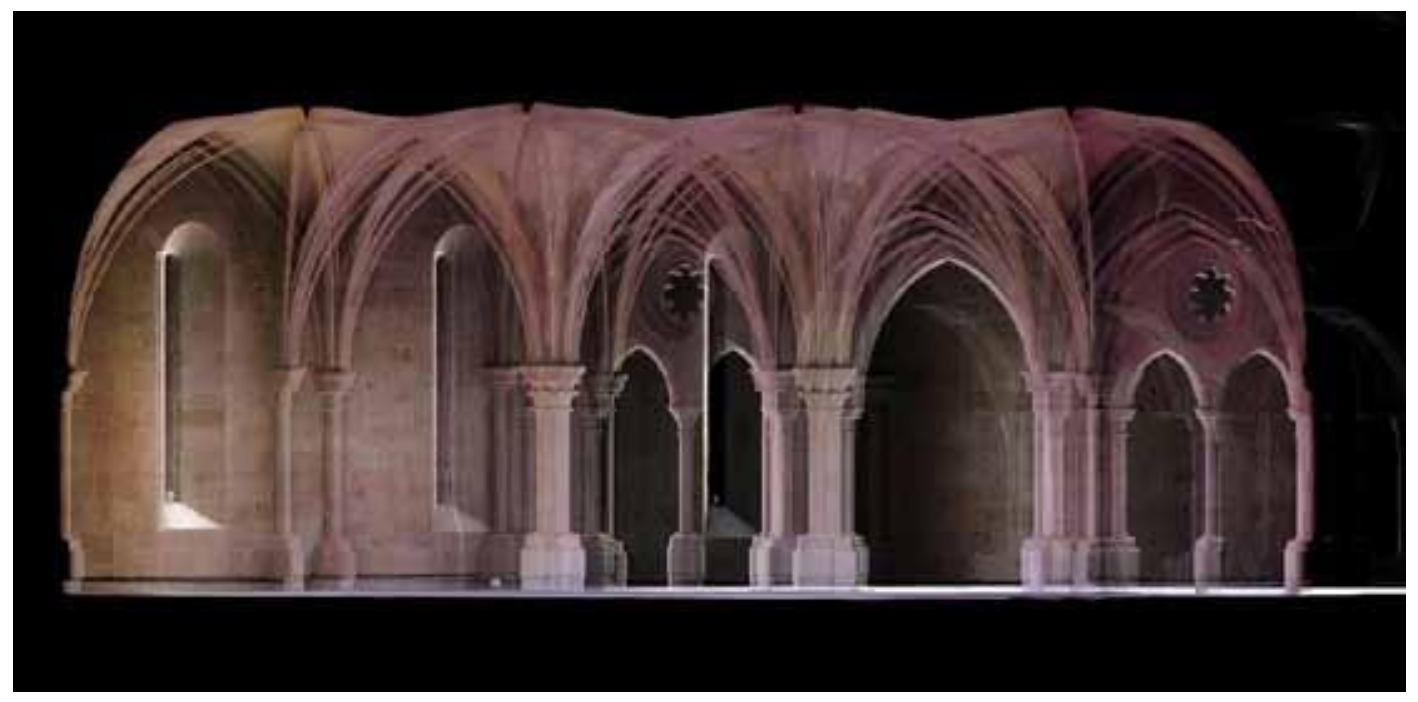

Figure 45. The internal scan of the church was completed before it became too dark tocontinue without artificial light ("The Abbey of New Clairvaux," 2018). 
The main objective of this project was to determine the possibility of using laser scanning technology to assist in ongoing maintenance work within the mine (Figure 46) (Figure 47) (Figure 48) (Figure 49) (Figure 50) (Figure 51).

\section{TOTAL TIME SPENT}

8 days onsite 2 persons team, 40 days data processing.

FINAL PRODUCT

Registered point cloud, Truview, CAD drawings, orthoimages.

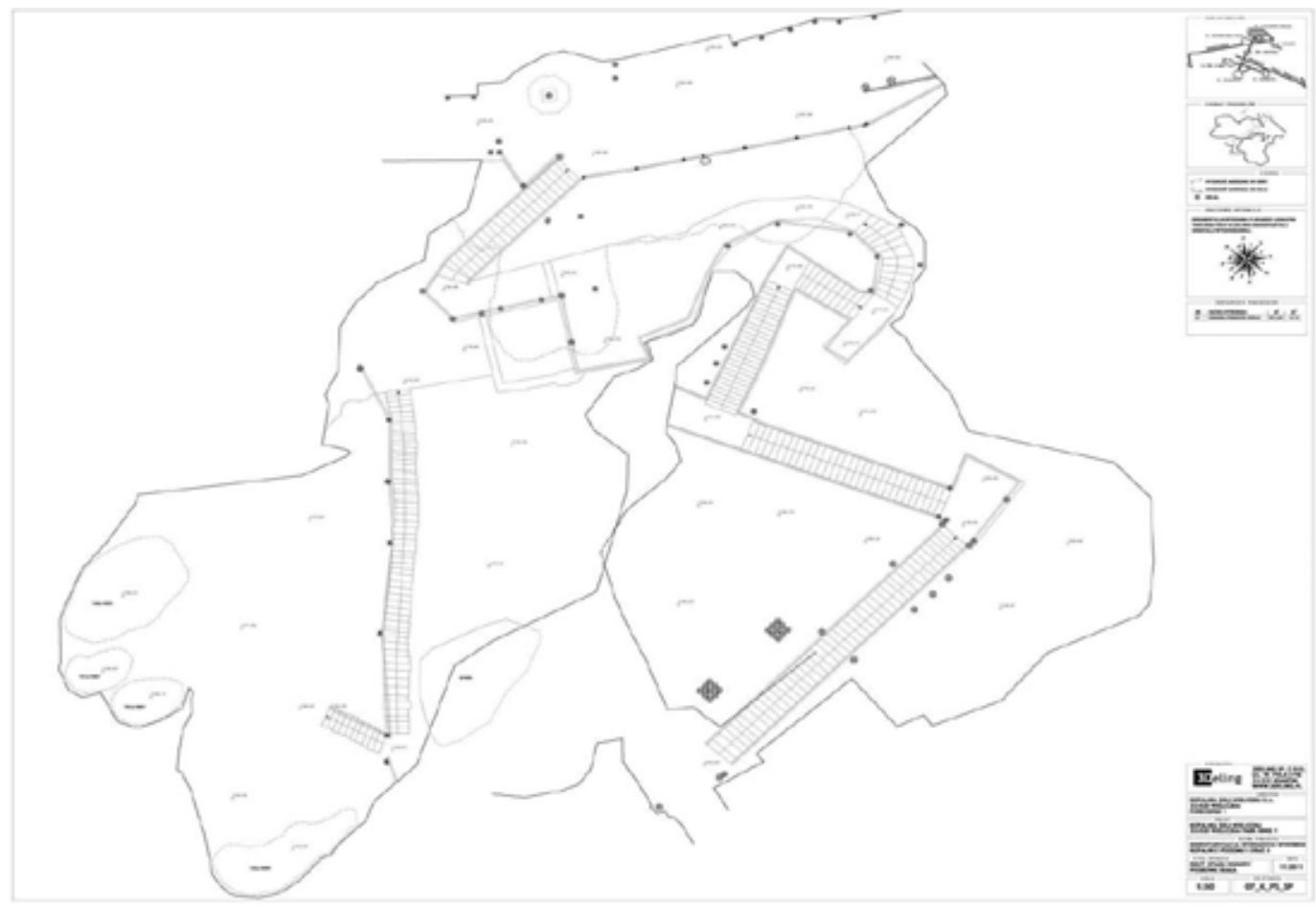



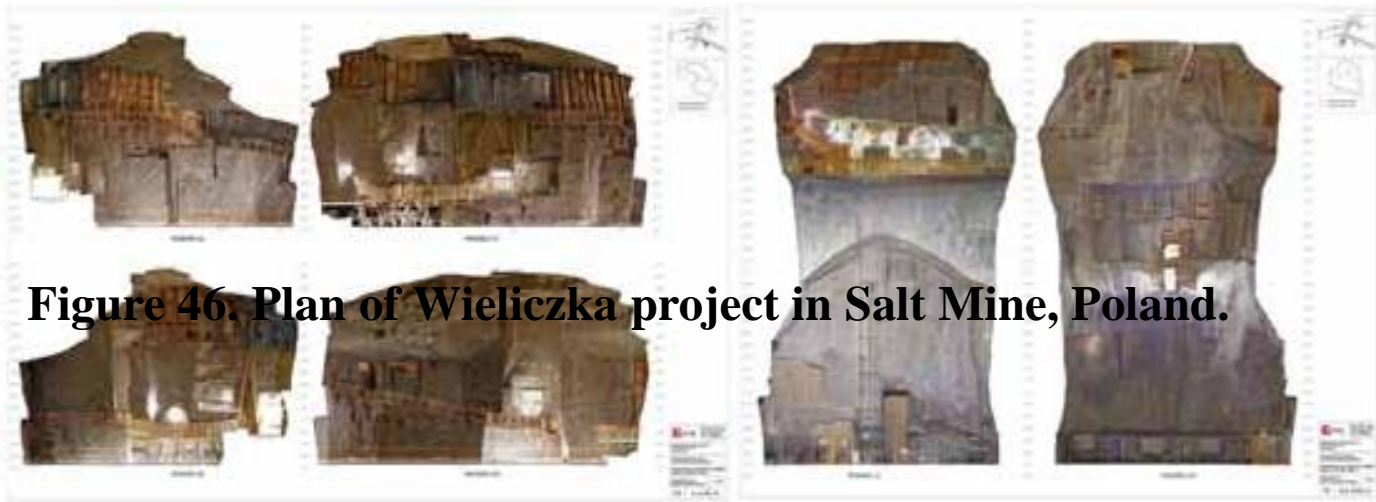

Figure 47. The project focused on corridors and underground rooms, both inside and outside the tourist route.
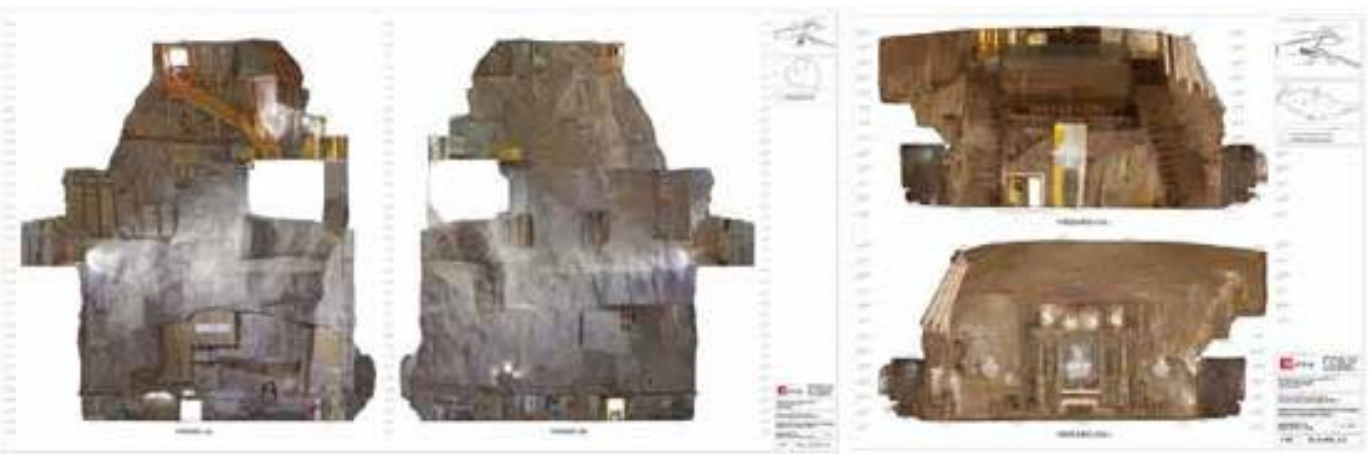
Figure 48. A three-dimensional film was also produced entirely for photographicpurposes.

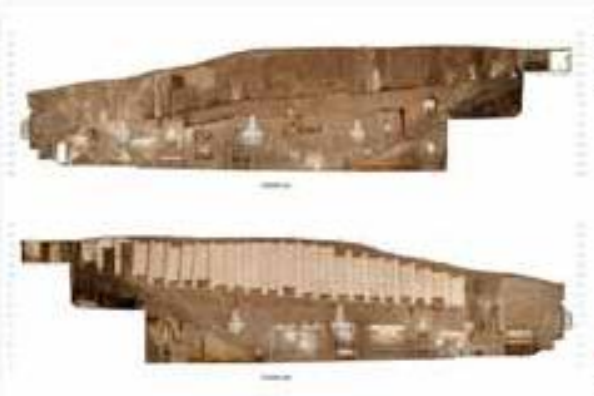

Figure 49. The research commissioned laser scanning technology.

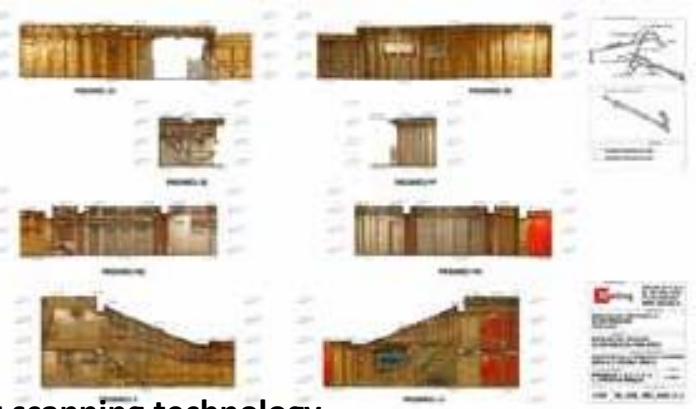

Figure 49. The research commissioned laser scanning technology.
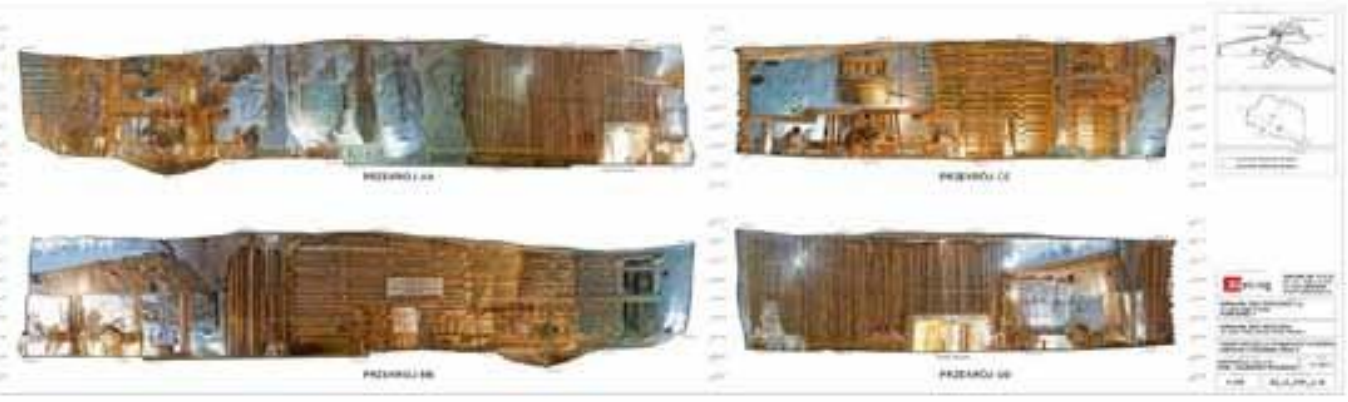

Figure 50. Sections of project after 3D Laser scanning application. 
INTERNATIONAL JOURNAL OF

MULTIDISCIPLINARY STUDIES IN ARCHITECTURE

\section{AND CULTURAL HERITAGE}

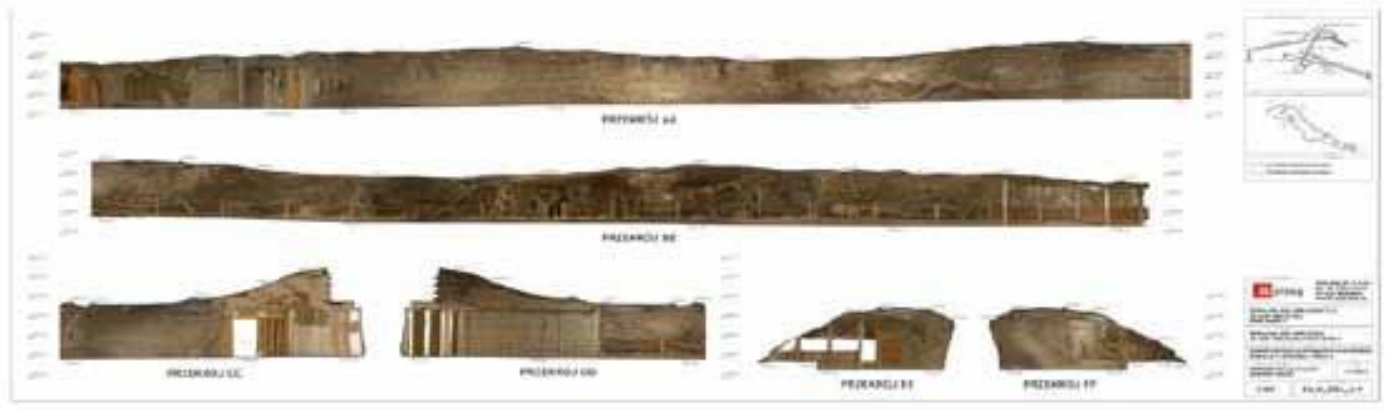

Figure 51. The film allowed the viewer to visualize the mine layout, which was difficult inthe real world (“3D laser scanning," 2018).

\section{The Uniejów Castle project}

The project was intended to document the current state of the exterior facades buildings to be used as the basis for the reconstruction / maintenance work planning (Figure 52) (Figure 53) (Figure 54) (Figure 55).

\section{TOTAL TIME SPENT}

1 day on site, 20 days for processing.

\section{FINAL PRODUCT}

CAD drawings and orthoimages of external facades.

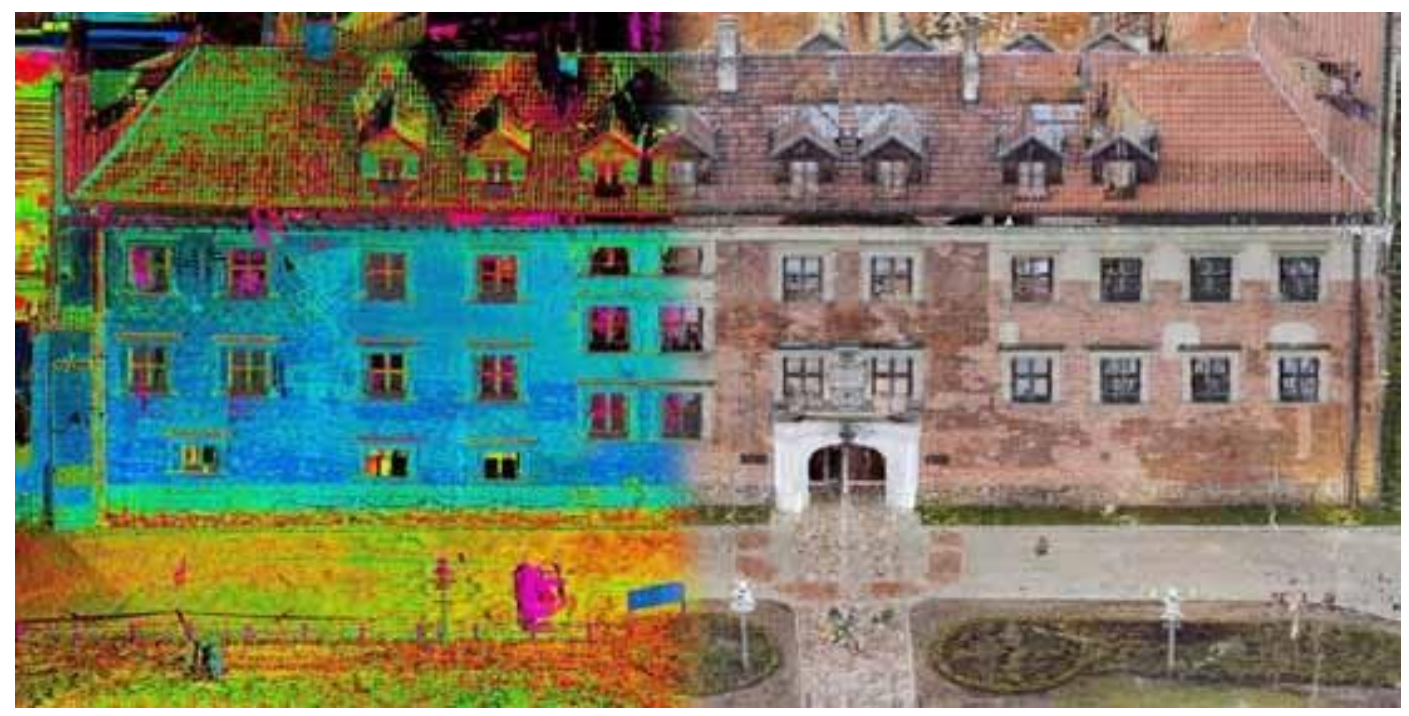


Figure 52. Laser scanning of Uniejów Castle in Uniejow, Poland ("Uniejów Castle," 2018).

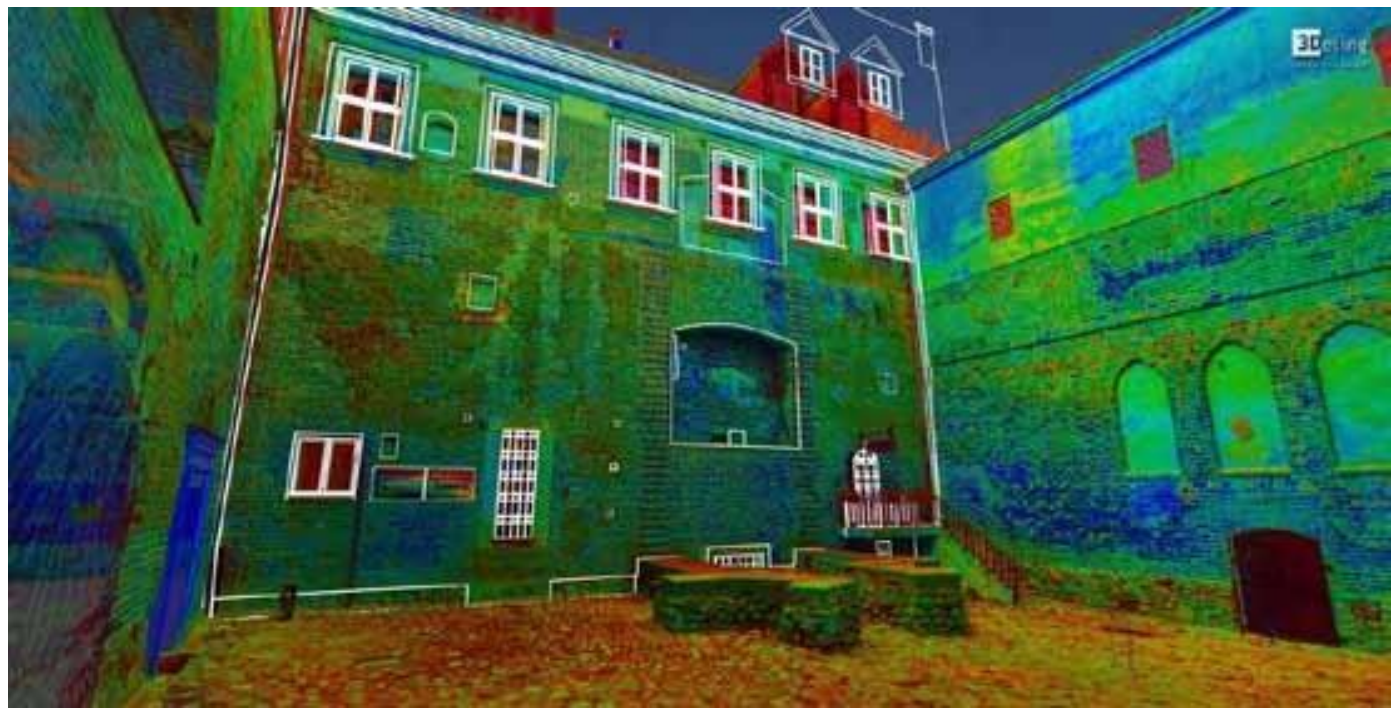

Figure 53. The building was scanned at the highest resolution settings for all external interfaces. Then, it was covered by the CAD with Orthoimages to show the full potential of laser scanning("3Deling - 3D Laser scanning," 2018). 


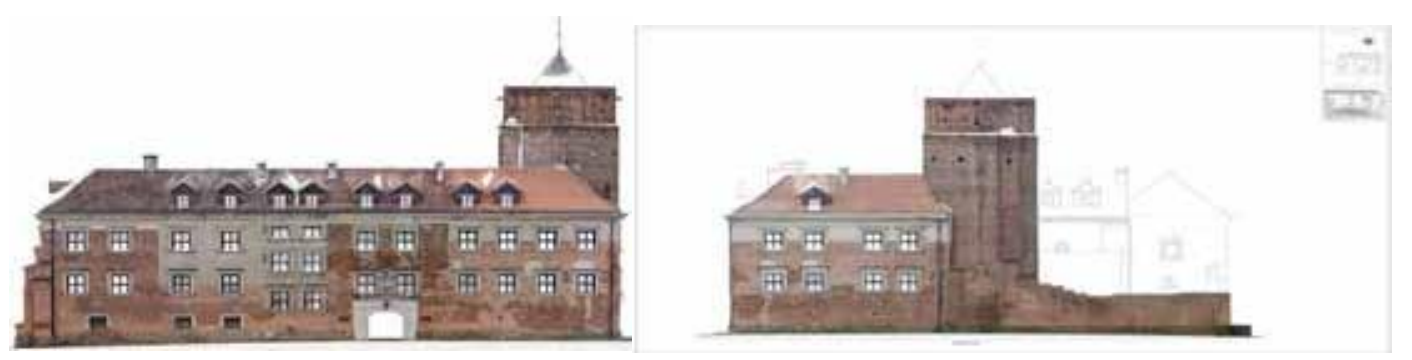

Figure 54. Elevations of CAD drawings were completed from the same dataset.
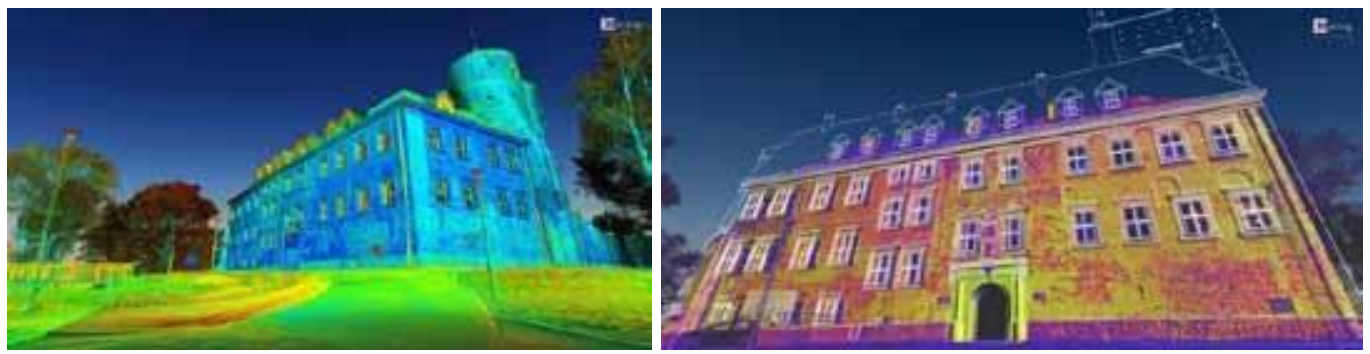

Figure 55. Survey work and a three-dimensional visualization of the site were produced.

\section{Historical façade project}

The purpose of this project was to record the historical façade of this building for registration purposes and specifying requirements of the project for heritage conservation (Figure 56) (Figure 57).

\section{TOTAL TIME SPENT}

1 day on site (10 scans), about 10 days processing in the office.

\section{FINAL PRODUCT}

Orthophotos, 3D BIM models.

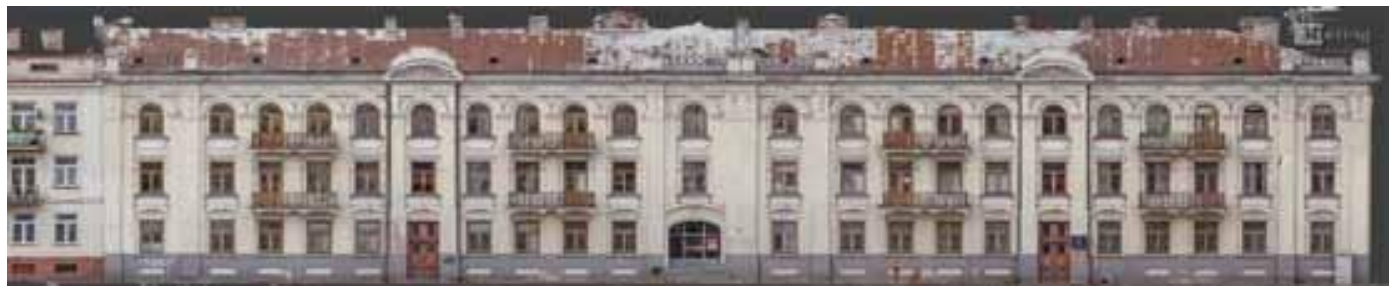


Figure 56. Historic Elevation in Plock in Plock, Poland ("Historic Elevation in Plock," 2018).

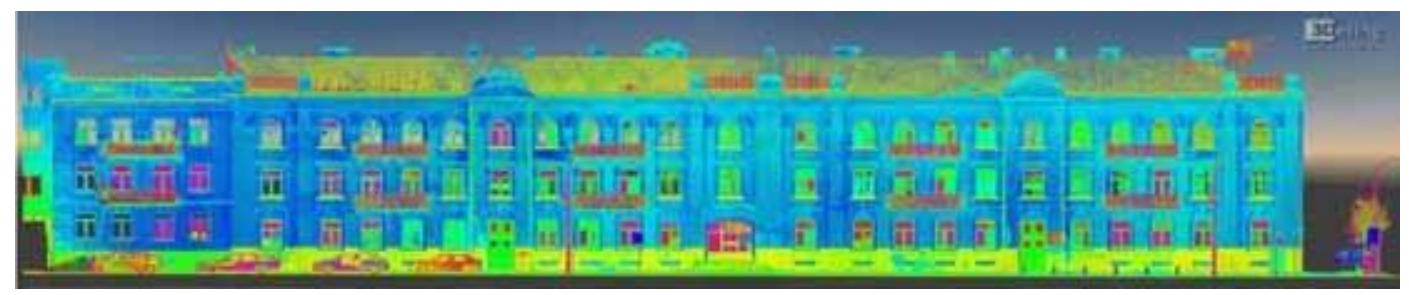

Figure 57. Many techniques have been employed to collect a comprehensive data set. The scan was used to add geometric features ("3D laser scanning," 2018).

\section{Results and discussion}


The process of heritage preservation determines the exploration of architecture and interior spaces then the implementation of treatment plan for the conservation, maintenance andrestoration of heritage. Digital technologies and biotechnology facilitate the preservation of heritage. The research discussed the importance of preserving architectural heritage, providing a great opportunity to stimulate tourism, promoting awareness and increasing knowledge in the field of technology and digital applications to preserve cultural heritage. Digital innovation and virtualization technologies enhance cultural heritage to analyze a new approach for the impact of material science and documentation in architectural heritage.

Digital techniques for Architecture and Interior conservation methods

\begin{tabular}{|ccc}
$\begin{array}{c}\text { Section 1: } \\
\text { Conservation } \\
\text { Restoration }\end{array}$ & $\begin{array}{c}\text { Section 2: } \\
\text { Material science } \\
\text { Biotechnology } \\
\text { Nanotechnology }\end{array}$ & $\begin{array}{c}\text { Section 3: } \\
\text { Documentation }\end{array}$ \\
3. conservation laser scanning & Photogrammetry\& virtual reality \\
\hline 2.Maintenance & 3.Restoration & 5.Reconstruction \\
Figure 58. Diagram of relationship between digital technology fields and \\
conservation heritage.
\end{tabular}

60 
Finally, there is a greatrelationship between cultural heritage and virtual systems. In addition, the application of technological methods contributes in preservation of heritage effectively and a safe manner. Consequently, the research discussed the connection between nanotechnology, nanomaterials, 3D laser scanning technology, photogrammetry, virtual reality and preservation heritage. Modern technologies can greatly help to document cultural heritage and produce 3D virtual models. accordingly, the use of these techniques and technological tools will led to green hritage (Figure 58).

\section{The research counculded many results as:}

1. Providing a great opportunity to stimulate tourism, promoting awareness and increasing knowledge in the field of technology and digital applications to preserve cultural heritage.

2. Digital technologies have had a tremendous impact on the production, preservation and utilization of cultural heritage.

3. Use of biomaterials will enhance Sustainable and more environmentally preserving heritage leading to green heritage.

4. There is a great relationship between cultural heritage and documentation, virtual reality, material science and technological tools in the preservation of heritage.

5. Virtual models provided a complete information to preserve the structure and space.

6. The digital and biological technologies used in heritage preservation contributed to create new possibilities to produce conservation treatments 
with improved properties of materials and new functions in the spaces.

7. Nanotechnology, Nano-materials and Nano-particle has an important impact in the cultural heritage and construction sector, improving the durability and enhanced performance of building materials, energy efficiency and safety effects.

1. Documentation of locations in detail provides complete information to preserve architecture through virtual models.

2. Exploring nanotechnologies and nanomaterials have an active role in preserving heritage and restoring cultural heritage.

3. The advanced 3D laser scanning systems and virtual reality allow for accurate documentation of locations in detail and provide complete information to preserve the structure through virtual models.

\section{Conclusion}

Digital technology has an essential role in the preservation and promotion of contemporary cultural heritage. The research involved many digital techniques, such as nanotechnology, nanomaterials, documentation, photogrametry, 3D laser scanning technology and virtual reality, which allowed detailed documentation of locations in detail, in addition, they provided complete information to preserve the structure and space through virtual models. In conculsion, many of the digital and biological technologies used in heritage preservation contribute to create new possibilities for the 
production of conservation treatments with improved properties of materials and new functions in the spaces. Therefore, nanotechnology and nanomaterials have an important impact in the cultural heritage and construction sector, improving the durability and enhanced performance of building materials, energy efficiency and safety effects. The research is recommended to apply these digital techniques with scientific institutions and cultural academies dedicated to heritage, civilization and research in their effective role in solving many of the problems related to preservation of architectural heritage

, in addition, finding appropriate documentation for these heritage spaces. It is also necessaryto establish standards and approaches for designers, architects when designing, implementing treatments for the protection and documentation of cultural heritage. Finally, research concludes that the spread of digital tools everywhere has a new relationship with the architecture heritage, and preserve it.

\section{Refrences}

3D laser scanning. (2013). Retrieved from

http://archc3d.fa.utl.pt/public html/3D laser scanning. (2018).

Retrieved from http://www.3deling.com/heritage/ 3D Laser

scanning. (2018). Retrieved from

http://www.scottpagedesign.com/ 


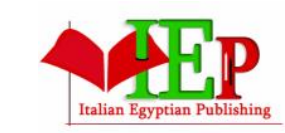

ISSN: $2735-4415$

\section{INTERNATIONAL JOURNAL OF \\ MULTIDISCIPLINARY STUDIES IN ARCHITECTURE \\ AND CULTURAL HERITAGE

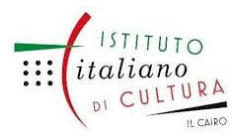

VOLUME 3, ISSUE 1, 2020, $1-68$.

www.egyptfuture.org/ojs/

3d scanning. (2018). Retrieved from

https://media.directionsmedia.net/directionsmag/channels/pressreleases/PT- ROCczechLR.jpg

3Deling - 3D Laser scanning. (2018). Retrieved from

http://www.3deling.com/Archaeology. (2018). Retrieved from

http://cisa3.calit2.net/arch/

Balliana, E., Ricci, G., Pesce, C., \& Zendri, E. (2016). Assessing the value of green conservation for cultural heritage: positive critical aspects of alreafy available methodologies. International Journal of Conservation Science, 7(1), 185-202.

Brusaporci, S. (2017). Digital Innovations in Architectural Heritage Conservation Emerging Research and Opportunities. IGI Global.

Documentation

(2018).

Retrieved romhttps://play.google.com/store/apps/details?id=com.dds.rosslynchapel

Digital Heritage Conference in Granada, Spain. (2015). Retrieved from http://ucsdnews.ucsd.edu/pressrelease/cisa3 stands out for research on cultural herita ge engineering at_2015_digi

Digital innovation can enhance cultural heritage. (2018). Retrieved from https://horizon-magazine.eu/article/digital-innovation-can-enhance-cultural-heritagehears- conference_en.html\#.WrOkVyzzYq8.facebook

Digital photogrammetry and laser scanning. (2018). Retrieved from http://ars.elscdn.com/content/image/1-s2.0-S1296207407001082-gr3.jpg

Digital survey of cultural Heritage. (2018). Retrieved from http://www.digitalsurveys.co.uk/ 


\section{INTERNATIONAL JOURNAL OF \\ MULTIDISCIPLINARY STUDIES IN ARCHITECTURE

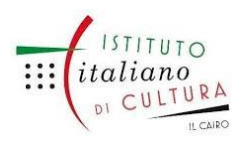

AND CULTURAL HERITAGE

Heritage Building Conservation. $\quad$ (2018). Retrieved from

https://conservationsolutionsinc.com/landings/view/heritage-building-conservation

Historic Elevation in Plock. (2018). Retrieved from ttp://www.3deling.com/portfolio-item/historicelevation-plock/

Initial Training Network for Digital Cultural Heritage. (2018). Retrieved from http://www.itn-

dch.eu/International training program in built heritage

conservation. (2010). Retrieved from

https://historicalcities.wordpress.com/2010/05/10/international-training-program-in-

built-heritage- conservation/

loannides, M., Martins, J., Žarnić, R., Lim, V. (2017). Advances in Digital Cultural Heritage (International Workshop, Funchal, Madeira, Portugal, June 28, 2017, Revised Selected Papers). Springer International Publishing.

Jonkers, H. (2014). Bio-Concrete - Henk Jonkers. Retrieved from http://syndebio.com/bio-concrete/

Kroftová, K., Šmidtová, M., Kuřitka, I., \& Škoda, D. (2017). Nanotechnology in the cultural heritage - influence of nanospensions adopted by nanoparticles of $\mathrm{TiO} 2$ for cleaning the surface of historical plasters. Stavební Obzor - Civil Engineering Journal, 26(3), 216-221. https://doi.org/10.14311/CEJ.2017.03.0019

Lazzara, G., \& Fakhrullin, R. (2018). Nanotechnologies and Nanomaterials for Diagnostic, Conservation and Restoration of Cultural Heritage. Elsevier.

LIMESTONE SCULPTURE CONSERVATION - RIVERSIDE CHURCH project. (2008). Retrieved from https://conservationsolutionsinc.com/projects/view/201/limestone-sculptureconservation-riverside- church/ 


\section{INTERNATIONAL JOURNAL OF \\ MULTIDISCIPLINARY STUDIES IN ARCHITECTURE

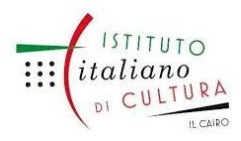

AND CULTURAL HERITAGE

living concrete. (2016). Retrieved from http://aakaariitb.in/blog/index.php?key1=mon122017-3

NaciYastikli. (2007). Documentation of cultural heritage using digital photogrammetry and laser scanning.

Journal of Cultural Heritage, 8(4).

ORNAMENTAL TERRA COTTA RESTORATION - RINGLING MUSEUM OF ART project. (2017).

Retrieved from https://conservationsolutionsinc.com/projects/view/605/ornamental-terracotta-restoration- ringling-museum-of-art/

Safe-by-Design nanotechnology for safer cultural heritage restoration. (2016). Retrieved from https://atlasofscience.org/safe-by-design-nanotechnology-for-safer-cultural-heritagerestoration/

Self-Healing Concrete. (2016). Retrieved from http://www.industrytap.com/self-healingconcrete-can-repair-cracks-bacteria/29051

Self-Healing Concrete Can Repair Its Own Cracks with Bacteria. (2015). Retrieved fromhttp://www.industrytap.com/self-healingconcrete-can-repair-cracks-bacteria/29051

SENATE CHAMBER METALS CONSERVATION - KANSAS STATE CAPITOL project. (1999). Retrieved from https://conservationsolutionsinc.com/projects/view/37/senate-chamber-metalsconservation-kansas- state-capitol/

Sierra-Fernandez, A., Gomez-Villalba, L. S., Rabanal, M. E., \& Fort, R. (2017). New nanomaterials for applications in conservation and restoration of stony materials: A review. MATERIALES DE CONSTRUCCIÓN, 67(325), 1-17. Retrieved from http://dx.doi.org/10.3989/mc.2017.07616 


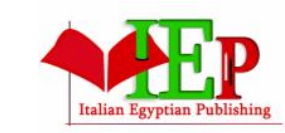

ISSN: $2735-4415$

\section{INTERNATIONAL JOURNAL OF \\ MULTIDISCIPLINARY STUDIES IN ARCHITECTURE \\ AND CULTURAL HERITAGE}

VOLUME 3, ISSUE 1, 2020, $1-68$.

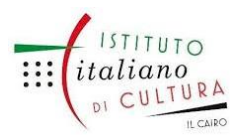

www.egyptfuture.org/ojs/

Srinivas, H. (2018). Towards Developing a Plan of Action for Heritage Conservation. Retrieved from https://www.gdrc.org/heritage/heritage-sowhat.html

The Abbey of New Clairvaux. (2018). Retrieved from

http://www.scottpagedesign.com/recent-projects/The Cathedral cloisters. (2018).

The Library of Congress (LOC). (2018). Retrieved from https://www.loc.gov/visit/tours/onlinetours/thomas- jefferson-building/exterior/

Tziviloglou, E., Pan, Z., Jonkers, H. M., \& Schlangen, E. (2017). Bio-based Self-healing Mortar: An Experimental and Numerical Study. Journal of Advanced Concrete Technology, 15(9), 536543. https://doi.org/10.3151/jact.15.536

UNESCO. (2003). Charter on the Preservation of the Digital Heritage. In the 32nd session of the General Conference of UNESCO (pp. 1-4). Retrieved http://www.unesco.org/new/fileadmin/MULTIMEDIA/HO/Cl/Cl/pdf/mow/charter preserva tion digital $h$ eritage_en.pdf

Uniejów Castle. (2018). Retrieved from http://www.3deling.com/portfolio-item/uniejow-castle/

Villa Ambron. (2018). Retrieved from http://michaelhaag.blogspot.com.eg/2017/09/zahraa-adelawad-has-sent- me-more.html

Visualisation \& Simulation. (2018). Retrieved from http://www.digitalsurveys.co.uk/sectors/oil-and-gas

What is Cultural Heritage. (2014). Retrieved from http://www.cultureindevelopment.nl/Cultural Heritage/What is Cultural Heritage

What is heritage conservation? A brief overview. (2018). Retrieved fromhttp://www.heritagemeaford.com/heritage-conservation-abrief-overview-article7what is nanotechnology. (2018). 
INTERNATIONAL JOURNAL OF

MULTIDISCIPLINARY STUDIES IN ARCHITECTURE

AND CULTURAL HERITAGE

ISSN: 2735-4415
VOLUME 3, ISSUE 1, 2020, 1-68.

www.egyptfuture.org/ojs/

Received: February 15, 2018

Accepted: April 20, 2018 